\title{
Wet Deposition and Long-range Transport of Major Ions Related to Snow at Northwestern Himalayas (India)
}

\author{
Anshu Sharma, U.C. Kulshrestha* \\ School of Environmental Sciences, Jawaharlal Nehru University, New Delhi 110067, India
}

\begin{abstract}
The present study was carried out to understand the snow chemistry with special emphasis on the estimation of wet deposition fluxes and transportation of ionic species to the Himalayan regions from December 2015 to March 2017 . All the snow samples were collected from three different sites of two locations, Jammu \& Kashmir and Himachal Pradesh. In Jammu and Kashmir we have selected two sites, (an urban area Leh and other one was semi-urban area Beerwah). In Himachal Pradesh, we selected a site at Nirmand village which was a rural area. At Leh and Nirmand village, samples were showing higher alkalinity than at Beerwah site. The $\mathrm{pH}$ values of snow at Leh and Nirmand were recorded above 5.6 except one sample of both the sites. However, at Beerwah site almost $60 \%$ of the samples were found acidic (below 5.6) in nature. All these three sites showed three different means of neutralization and $\mathrm{pH}$ control. The study revealed that the high $\mathrm{pH}$ value of snowfall at Leh site could be due to the presence very high value of $\mathrm{Ca}^{2+}$ whereas the moderate $\mathrm{pH}$ at Nirmand village may be due to moderate concentration of $\mathrm{Ca}^{2+}$ and high $\mathrm{NH}_{4}{ }^{+}$. In contrast at Beerwah site, low pH is probably due to very low concentrations of all the major cations. This study also suggested that non-sea salt sources contributed a significant fraction of $\mathrm{SO}_{4}{ }^{2-}, \mathrm{K}^{+}, \mathrm{Ca}^{2+}$, and $\mathrm{Mg}^{2+}$. However, on average, a significant amount of $\mathrm{HCO}_{3}{ }^{-}$was measured at all the three sites, indicating a substantial role of crustal sources in the study sites. Results of this study showed that these ionic species are contributed by local as well as long-distance sources in the region. Backward airmass trajectory analysis revealed that the ionic species were contributed by the airmasses coming from North Atlantic Ocean, Africa, Europe, Middle East, and Mediterranean region to all these sites through long-range transport (LRT).
\end{abstract}

Keywords: Snow; pH; Ionic chemistry; Wet deposition flux; Back trajectory analysis.

\section{INTRODUCTION}

Increasing emissions of atmospheric aerosols significantly affect air quality (Allen et al., 2016). The IPCC (2014) report warns of severe consequences on global and regional atmospheric processes due to increasing aerosol particles. Deposition of anthropogenic constituents via wet and dry removal processes from the atmosphere has adverse impacts on terrestrial and aquatic ecosystems (Seinfeld and Pandis, 2006). Snowfall is considered as one of the most active wet removal processes for air pollutants at high altitude sites. It deposits significant amounts of bio geochemically important trace chemical species on various surfaces on Earth. Watersoluble ionic species present in the Himalayan snow is substantially affected by air pollutants from long-range transport of various anthropogenic sources (Kulshrestha and Kumar, 2014). Previous studies on snow chemistry reveals that the combustion of fossil fuel and biomass burning were

\footnotetext{
* Corresponding author.

E-mail address: umeshkulshrestha@gmail.com
}

dominantly responsible for air pollution (Zhang et al., 2013; Kumar et al., 2015, 2016). In general, snow composition shows spatial variation which largely depends upon the sources, characteristics of sampling site, elevation from the sea level, atmospheric conditions, sampling procedure and the transport of air pollutants, etc., (Marinoni et al., 2001). Airmass trajectories combined with snow chemistry data provide valuable information about the origin of air pollutants (Fleming et al., 2012; Kulshrestha and Kumar, 2014) and their impact on various ecosystems through deposition processes.

Therefore, extensive study has been undertaken on snow composition in the western countries (Reynolds, 1983; Jenkins et al., 1987; Gunz and Hoffman, 1990; Marinoni et al., 2001; Toom-Sauntry and Barrie, 2002; Rohrbough et al., 2003; Walker et al., 2003; Niu et al., 2013; Xu et al., 2013; Zhang et al., 2013). The Himalayas are remotely located from industrialized urban centers; and they provide ideal locations not only to study the evolution of atmospheric constituents but also in monitoring the tropospheric chemistry (Cunningham and Zoller, 1981). The Himalayas are considered as the most sensitive ecosystem as far as the atmospheric deposition is concerned (Kuylenstierna et al., 2001; Zhang et al., 2012; Tiwari et al., 2012; Liu et al., 2013; Balestrini et al., 2014; 
Bisht et al., 2017). It is adversely affected by local and longrange transport of pollutants (Tiwari et al., 2012; Kulshrestha and Kumar, 2014; Roy et al., 2016; Bisht et al., 2017). Tourist activities, transportation, and other human activities are some of the local factors that significantly affect snow chemistry and adversely impact the aquatic and terrestrial ecosystems. In spite of its sensitivity, annual and seasonal depositions of various chemical species are poorly understood. There are very few studies reported on aerosols, rainwater and snow geochemistry in the Himalayan region (Ahmad and Hasnain et al., 2001; Gajananda et al., 2005; Tiwari et al., 2012; Kuniyal et al., 2013; Roy et al., 2016; Bisht et al., 2017). Similarly, in the western Himalayan region of India very few studies were done on fresh snowfall chemistry (Kapoor and Paul, 1980; Naik et al., 1995; Lone and Khan, 2007; Kulshrestha and Kumar, 2014; Kumar et al., 2015, 2016). Comparatively low concentration of air pollutants have been reported in the Himalayas on fresh snow chemistry (Marinoni et al., 2001; Shrestha et al., 2002; Kang et al., 2004; Lone and Khan, 2007; Huang et al., 2012; Kumar et al., 2015, 2016; Bisht et al., 2017). Thus, it represents the remotest part of India and could be considered as a reference for further studies. Hence, the main objective of this study was to investigate fresh snow chemistry in the Himalayas, ascertaining the local and long-range sources using NOAA HYSPLIT trajectories. The secondary objective was to investigate the marine and non-marine contributions in snow and discuss their environmental implications.

\section{METHODOLOGY}

\section{Sampling Sites}

Three sites from the Western part of the Himalayan region, which are having different land use land cover pattern (http://bhuvan.nrsc.gov.in) (Fig. 1), sources and population densities were selected for the study. Among which two sites were Leh and Beerwah located in the state of Jammu and Kashmir while the third one was Nirmand village in Himachal Pradesh, India. The location of all sites has been shown in Fig. 1. Jammu \& Kashmir state is divided into three regions- Ladakh, the Jammu division and the Kashmir Valley division. Each site has been separately described in subsequent sections.

\section{Leh}

Leh is one of the districts of the Ladakh division which represents India's northern boundary adjacent with Pakistan and China, covers approximately 52.6\% area of Jammu \& Kashmir. The geographical coordinates of Leh are $34.15^{\circ} \mathrm{N}$ and $77.57^{\circ} \mathrm{E}$ and $2.3 \mathrm{~km}$ to $5 \mathrm{~km}$ above mean sea level (amsl). The Topography of Leh is quite uneven and covered mostly with mountains. Ladakh, Karakoram, and Zanskar are three parallel ranges of the Himalayas. Ladakh lies in the rain shadow region of the Himalayas. The artic type of climate prevails in the Ladakh region. Thus, Ladakh is considered as 'cold desert' which is located on the western end of the Himalayas with sparse vegetation. At Leh, the recorded minimum temperature in winters is $-28^{\circ} \mathrm{C}$ whereas maximum temperature in summers is $35^{\circ} \mathrm{C}$. Average annual rainfall in Leh is about $115 \mathrm{~mm}$. The adverse climatic conditions and inaccessibility of the region are reflected in the limited population of around 150000 in Leh district. The Ladakh region is mainly comprised of Palaeozoic to Cretaceous sediments, meta-sediments, granitic intrusions and the Ladakh batholith. The latter is an intermediate rock which is located to the north of the Indus River (Dortch et al., 2008).

\section{Beerwah}

Beerwah is a sub-district of Central Kashmir which is a part of the Budgam district of Jammu \& Kashmir. The Beerwah

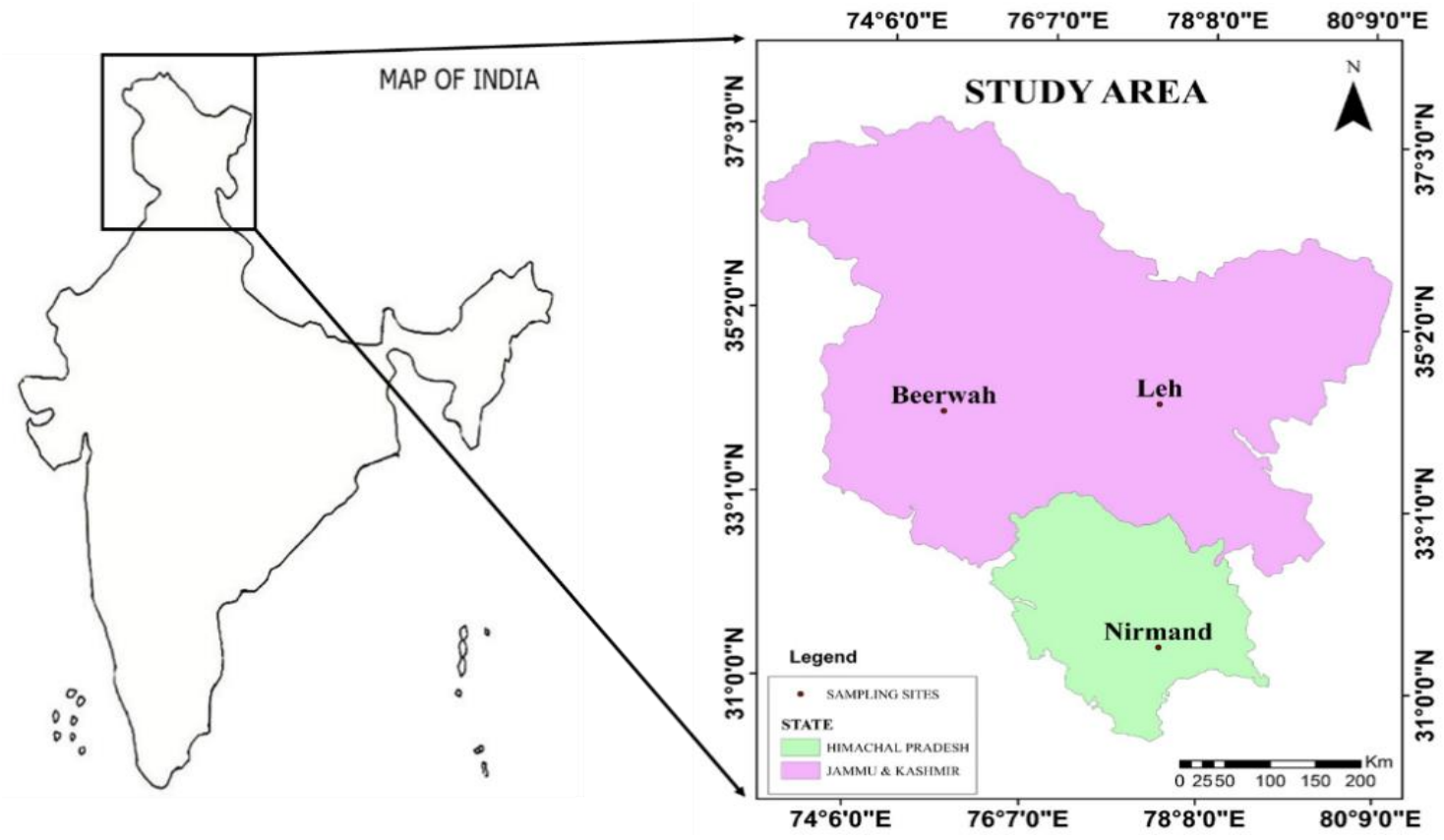

Fig. 1. Map showings the sampling sites. 
lies between $74.59^{\circ} \mathrm{E}$ and $34.01^{\circ} \mathrm{N}$ at an elevation of $1.7 \mathrm{~km}$ amsl. Karewas, plateau-like terraces kind of agricultural landscape are predominantly present there. Agriculture is the main occupation of the people in this area. It is located about $30 \mathrm{~km}$ from Srinagar city in South-West direction. The main sources of pollution are automobiles and brick kilns, which are situated about $3-4 \mathrm{~km}$ from the main town. Panjal traps forming hilly and mountainous terrain of the district with hard formations of igneous and metamorphic rocks. The Karewa formation and alluvium of Quaternary and Tertiary age (Plio-Pleistocene) underlie the valley area and consists of alternate bands of sand, silt, gravel \& clay, interspersed at two to three levels locally by glacial boulder beds. This formation of Plio-Pleistocene age lies dis-conformably over the older rocks ranging in age from Cambrian to Triassic.

\section{Nirmand}

Kullu is a broad open valley which is sandwiched between the Lower Himalayan, Pir Panjal and Great Himalayan Ranges. Nirmand village (the study area) is located in Kullu district of Himachal Pradesh, India $\left(31.43^{\circ} \mathrm{N}\right.$ and $\left.77.65^{\circ} \mathrm{E}\right)$. Nirmand village is situated on the border of Kullu and Shimla district, and is often called as Kashi of the Himalayas. It is situated nearly $87 \mathrm{~km}$ away in South from the Kullu District headquarters and about $150 \mathrm{~km}$ north from Shimla. Their climate is characterized by the cold and dry condition which over the year consists of three seasons. The summer season in Kullu which is from March to June has maximum temperature reaching $30^{\circ} \mathrm{C}$ during the day with nights retaining a bit of chill. Winters are characterized by snowfall and heavy frosts from December to January with the possibility of early snowfalls occurring in November also. The geological structure of this region is mainly formed by granites (unclassified) formations and it has Udalfs (20) type of soil cover which is high base status of humid regions. The region is without vegetation cover. Fresh snow samples were collected using the snow collector at three sites in Western Himalayan region of India: (1) Leh (the main city of Ladakh): represents urban site having lots of tourist activities (2) Beerwah: this is semi-urban site (3) Nirmand: this site in the Kullu valley represent rural site away from the urban site Shimla, considered as a green belt area due to less or no tourist activity. Total 40 snow samples were collected during the sampling period-13 from Leh, 11 from Beerwah and 16 from Nirmand. Sample collector (a plastic tray having $\sim 30 \mathrm{~cm}$ diameter) was placed about $\sim 2 \mathrm{~m}$ above the ground level usually on rooftops or at elevated places. Samples were collected on an event by-event basis from December 2015 to January 2017. Sampling was done according to the methodology adopted by Kumar et al. (2015). The collector was thoroughly washed with Milli-Q and air dried before, and after each time the sample was collected. The collector was kept on the rooftop during the snowfall event and removed immediately after the collection. Fresh snowfall samples deposited on the collector was immediately transferred into pre-cleaned polypropylene bottles. Biological degradation of the samples was avoided by adding Thymol $(<5 \mathrm{mg})$ to each batch. Ambient conditions of the samples were preserved by storing them in a refrigerator. Samples were brought in the laboratory within 15 days from their collection and preserved for further analysis. Measurements of $\mathrm{pH}$ and $\mathrm{EC}$ of snow samples were done immediately so that the samples could be processed further for major cations and anions. Field blanks were also collected and analyzed using procedures similar to the snow sample.

\section{Chemical Analysis and Quality Control}

The major water-soluble ionic species such as cations $\left(\mathrm{Na}^{+}, \mathrm{K}^{+}, \mathrm{NH}_{4}^{+}, \mathrm{Ca}^{2+}, \mathrm{Mg}^{2+}\right)$ and anions $\left(\mathrm{Cl}^{-}, \mathrm{F}^{-}, \mathrm{SO}_{4}{ }^{2-}, \mathrm{NO}_{3}{ }^{-}\right.$, $\mathrm{HCO}_{3}{ }^{-}$) were quantitatively determined by Ion Chromatograph (Metrohm 883Basic IC Plus). Metrosep C4-100/4.0 column and an eluent of $1.7 \mathrm{mmol} \mathrm{L}^{-1}$ nitric acid and $0.7 \mathrm{mmol} \mathrm{L}^{-1}$ Dipicolinic acid at a flow rate of 0.9 without suppressor was used for determination of cations. While Metrosep A SUPP 4, 250/4.0 column and an eluent of $1.8 \mathrm{mmol} \mathrm{L}^{-1} \mathrm{Na}_{2} \mathrm{CO}_{3}$ and $1.7 \mathrm{mmol} \mathrm{L}^{-1} \mathrm{NaHCO}_{3}$ at a flow rate of 1.0 with Metrohm suppressor technique were used for determination of anions. $\mathrm{HCO}_{3}{ }^{-}$was determined by using $0.0025 \mathrm{NH}_{2} \mathrm{SO}_{4}$. The details of the chemical analysis procedure are discussed elsewhere (Singh et al., 2014).

\section{The Data Quality Control}

Ion balance technique was used to check the quality of analytical data of water-soluble ionic species for all sites (WMO, 1994). The mean ionic ratio helps us to know the reliability of the analytical results. If all the major anions and cations are analyzed, the ratio is expected to the present study, the ratio was found to be $1.08 \pm 0.16,1.4 \pm 0.13$ and $1.04 \pm 0.14$ for Leh, Beerwah, and Nirmand, respectively. The higher significant correlation coefficients between $\Sigma^{-}$ and $\Sigma^{+}$were observed over all the sites. The ratio was found to be close to unity over Leh and Niramnd site suggesting the completeness and correctness of the analytical measurements. However, the ratio over Beerwah shows significant deviation from unity, suggesting the acidic nature of snow where acidic component is not completely neutralized by basic cation.

\section{Wet Deposition fluxes through Snowfall Deposition}

Wet deposition flux (F) of all ionic species was calculated during the winter season of 2015-2017 by using the formula

$\mathrm{F}=(\mathrm{C} \times \mathrm{V}) / \mathrm{A}$

here:

$\mathrm{F}=$ Deposition Flux in meq $\mathrm{m}^{-2}$

$\mathrm{C}=$ Average concentration of Ionic components in $\mu \mathrm{eq} \mathrm{L}^{-1}$

$\mathrm{V}=$ Volume of snow (36.98 L for Beerwah and Nirmand site, and $16.86 \mathrm{~L}$ for Leh),

$\mathrm{A}=$ Area of the tray $\left(314 \mathrm{~cm}^{2}\right)$.

\section{The Contribution of Ionic Species Through Different Sources}

We have used the following methodology to identify the source of contributed ionic species:

\section{Marine Contribution}

Equivalent ratio and enrichment factor (EF) of measured ions viz. $\mathrm{Cl}^{-}, \mathrm{SO}_{4}{ }^{2-}, \mathrm{Mg}^{2+}, \mathrm{K}^{+}, \mathrm{Ca}^{2+}$ were calculated in order 
to determine the marine and non-marine contributions in snow. Sodium was taken as the reference element in above calculations assuming all sodium coming from marine sources (Keene et al., 1986). The sea salt fraction (ssf) and non-sea salt fraction (nssf) were assessed by using the formula given below (Kumar et al., 2015).

$\%$ ssf $=100 / E F_{\text {sea }}$ water

here $E F_{\text {sea water }}=\frac{\left[\mathrm{X} / \mathrm{Na}^{+}\right]_{\text {show melt }}}{\left[\mathrm{X} / \mathrm{Na} \mathrm{a}^{+}\right]_{\text {sea water }}}$

where $[\mathrm{X}]$ is the concentration of desired ionic species $\left(\mu\right.$ eq $\left.\mathrm{L}^{-1}\right)$.

$\%$ nssf $=100-\%$ ssf

The EF > 1, suggested significant influences of other sources instead of marine sources. Norman et al. (2001) reported non- marine fraction by the entrainment of atmospheric particulate matters in precipitation occurring along the air mass trajectories.

\section{Non-marine Contribution}

Non- marine sources can be categorized into two major categories i.e., crustal and anthropogenic sources. Out of these two, anthropogenic sources mostly enhance the acidity of precipitation while crustal sources decrease the acidity by buffering of the acidifying species (Rodhe et al., 2002; Kulshrestha, 2013). Due to opposite characteristics in controlling acidity of precipitation, it is essential to quantify separately the non-marine fraction into crustal associated fractions and anthropogenic fractions. We have termed crustal associated fractions which has fractions of acidic components $\left(\mathrm{SO}_{4}{ }^{2-}, \mathrm{NO}_{3}{ }^{-}\right)$present as salt of calcium i.e., $\mathrm{CaSO}_{4}$ or $\mathrm{Ca}\left(\mathrm{NO}_{3}\right)_{2}$. We have followed the approach of Kulshrestha et al. (1997) and Jain et al. (2000) to calculate the contribution of crustal associated fraction and anthropogenic fraction of ionic species. For the calculation of the crustal associated fraction (CF) of major ionic components, $\mathrm{nssCa}^{2+}$ was considered as reference element in snowfall samples (Kulshrestha et al., 2003). The presence of crustal components in the form of $\mathrm{nssCa}^{2+}$ has been reported in precipitation globally (Rahn, 1976; Rodhe et al., 2002; Kulshrestha et al., 2003; Budhavant et al., 2014). Percent crustal fraction (CF) was calculated as follows

$\% \mathrm{CF}=100 / E F_{\text {Soil }}$
$E F_{\text {Soil }}=\left[\frac{y}{n s s C a^{2+}}\right]_{\text {snowfall }} /\left[\frac{y}{n s s C a^{2+}}\right]_{\text {soil }}$

here:

$\mathrm{y}=$ nss concentration of ionic species $\left(\mathrm{nssSO}_{4}{ }^{2-}, \mathrm{nssCa}^{2+}\right.$, $\mathrm{nssK}^{+}, \mathrm{nssMg}^{2+}, \mathrm{NO}_{3}^{-}, \mathrm{NH}_{4}{ }^{+}$and $\left.\mathrm{F}^{-}\right)$in $\mu \mathrm{eq} \mathrm{L}^{-1} ;\left(\mathrm{y} / \mathrm{nssCa}^{2+}\right)$ Soil is taken as standard ratio of local soils.

Then, the percent Anthropogenic (Anthro) fractions of each component were calculated as follows
$\%$ Anthro $_{\mathrm{x}}=\% \mathrm{nss}_{\mathrm{x}}-\% \mathrm{CF}_{\mathrm{x}}$

Average contribution of different sources: The average contribution of different sources viz. marine, crustal and anthropogenic was calculated by the following formula:

Average marine $\%=\frac{\sum X_{s s f}}{\sum X_{\text {Total }}} \times 100$

here $\sum \mathrm{X}_{\mathrm{ssf}}=$ Sum of concentration of all ssf values in each air mass cluster in $\mu$ eq $\mathrm{L}^{-1}$.

$\sum \mathrm{X}_{\text {Total }}=$ Sum of concentration of all components in each air mass cluster in $\mu \mathrm{eq} \mathrm{L}^{-1}$.

Average crustal $\%=\frac{\sum X_{C F}}{\sum X_{\text {Total }}} \times 100$

here $\sum \mathrm{X}_{\mathrm{CF}}=$ Sum of concentration of all Crustal Fraction values in each air mass cluster in $\mu \mathrm{eq} \mathrm{L}^{-1}$.

Average Anthropogenic $\%=100-$ Average marine $\%$ -

Average crustal\%

\section{Back Trajectory Analysis}

Three-days back trajectory analysis was also performed (Figs. 6(a)-6(c)) for the confirmation of the possible sources of pollutants over the Himalayan region. Backward airmass trajectories for $72 \mathrm{~h}$ of $2000 \mathrm{~m}$ above ground level were calculated using the geographic information system (GIS) based software, TrajStat for all snowfall samples (Wang et al., 2009).

\section{The Neutralization Factor of the Ionic Species}

Kaya and Tuncel (1997) reported that the acidification potential of wet precipitation is mainly determined by the presence of $\mathrm{HNO}_{3}, \mathrm{H}_{2} \mathrm{SO}_{4}$, and organic acids, whereas alkaline (basic) substances such as $\mathrm{NH}_{3}, \mathrm{MgCO}_{3}$ and $\mathrm{CaCO}_{3}$ are primarily responsible for their neutralization. Hence, the relative abundance of these acidic and alkaline species greatly determines the $\mathrm{pH}$ of precipitation. Cations such as $\left(\mathrm{Ca}^{2+}, \mathrm{Mg}^{2+}\right.$, and $\left.\mathrm{NH}_{4}^{+}\right)$react with acids $\left(\mathrm{H}_{2} \mathrm{SO}_{4}\right.$ and $\left.\mathrm{HNO}_{3}\right)$ to form $\mathrm{NO}_{3}{ }^{-}$and $\mathrm{SO}_{4}{ }^{2-}$ salts in the atmosphere.

The neutralization factor of these species were calculated by the following formula

$N F_{X i}=\frac{\left[X_{i}\right]}{\left[\mathrm{NO}_{3}^{-}+n s s \mathrm{SO}_{4}^{2-}\right]}$

where $[\mathrm{Xi}]=$ The concentration of desired ionic species i.e., nss $\mathrm{Ca}^{2+}$, nss $\mathrm{Mg}^{2+}$ and $\mathrm{NH}_{4}{ }^{+}$in $\mu$ eq $\mathrm{L} \mathrm{L}^{-1}$.

\section{RESULTS AND DISCUSSION}

\section{pH of Snow}

The $\mathrm{pH}$ of snow samples at Leh site ranged from 7.02 to 8.11 with an average of $7.48 \pm 0.38$, at Nirmand site varies 
from 5.30 to 7.09 with an average $6.39 \pm 0.48$ (Fig. 2), a similar range of $\mathrm{pH}$ at Mukteshwar site, Nainital and Kullu, in the north western Himalayan region have been reported by Tiwari et al. (2012), Kumar et al. (2015) and Bisht et al. (2017), respectively. As alkaline precipitation is considered to be a typical feature of the Indian region, the snow samples were observed with $>5.6 \mathrm{pH}$ due to its enrichment of suspended atmospheric dust with calcium carbonates (Kulshrestha et $a l ., 2003)$. Influence of natural dust particles in the rainwater chemistry has been reported over India (Delhi) by Kulshrestha et al. (1996, 2003); Jain et al. (2000). The pH of precipitation is usually measured at 5.6 in a clean atmosphere owing to the equilibration with atmospheric $\mathrm{CO}_{2}$ (Charlson and Rodhe, 1982). The enrichment of natural particles with carbonate and bicarbonates of calcium that eventually neutralize the resulting acidity. At Beerwah site, the $\mathrm{pH}$ was found to be slightly acidic and vary from 5.18 to 6.47 with the mean 5.77 \pm 0.37 . Kumar et al. (2016) have also reported an almost similar range of $\mathrm{pH}$ at Gulmarg site. Of this, about $45 \%$ of total snow samples were found to be acidic (below 5.6) at this site. Many co-workers have been also found the similar range of $\mathrm{pH}$ in precipitation at different sites of Himalayan region (Valsecchi et al., 1999; Liu et al., 2013; Kulshrestha and Kumar, 2014; Roy et al., 2016).

\section{Deposition of Major Ions in Snow}

The average concentration of ionic species at three sites (Leh, Beerwah, and Nirmand) over Western Himalayan regions of India along with the minimum and maximum concentrations in snow collected during the winter season of 2015-2016 and 2016-2017 is presented in Table 1. The pH and conductivity of snow samples have also been shown in
Table 1. At Leh site the mean concentration $\left(\mu \mathrm{eq} \mathrm{L}^{-1}\right)$ of cations in snow samples were found in the following order $\mathrm{Ca}^{2+}>\mathrm{Mg}^{2+}>\mathrm{NH}_{4}^{+}>\mathrm{Na}^{+}>\mathrm{K}^{+}$whereas the abundance of anions were as follow $\mathrm{HCO}_{3}{ }^{-}>\mathrm{Cl}^{-}>\mathrm{SO}_{4}{ }^{2-}>\mathrm{NO}_{3}{ }^{-}>\mathrm{F}^{-}$. At Beerwah site the mean concentration $\left(\mu \mathrm{eq} \mathrm{L}^{-1}\right)$ of cations were found in the following order $\mathrm{Ca}^{2+}>\mathrm{NH}_{4}{ }^{+}>\mathrm{Mg}^{2+}>\mathrm{Na}^{+}$ $>\mathrm{K}^{+}$whereas the anions were found as follow $\mathrm{HCO}_{3}{ }^{-}>\mathrm{Cl}^{-}$ $>\mathrm{SO}_{4}{ }^{2-}>\mathrm{NO}_{3}{ }^{-}>\mathrm{F}^{-}$. At Nirmand site the mean concentration of were like $\mathrm{NH}_{4}{ }^{+}>\mathrm{Ca}^{2+}>\mathrm{Na}^{+}>\mathrm{K}^{+}>\mathrm{Mg}^{2+}$ for cations and $\mathrm{HCO}_{3}^{-}>\mathrm{Cl}^{-}>\mathrm{SO}_{4}{ }^{2-}>\mathrm{NO}_{3}^{-}>\mathrm{F}^{-}$for the anions. Their percentage contribution in the snow samples has been calculated and depicted in Fig. 3 for all the sites.

At the Leh and Beerwah site, the $\mathrm{Ca}^{2+}$ ions were the most dominant whereas at Nirmand site it was much lower. At Leh site, the average concentration of $\mathrm{Ca}^{2+}$ accounts for approximately $18 \%$ of all ions and $42 \%$ among all cations, whereas at Beerwah site it accounts approximately $12 \%$ of all ions and $33 \%$ among all cations. It was observed that the average concentration of $\mathrm{Ca}^{2+}$ at Beerwah site was lower than Gulmarg (Kumar et al., 2016) (Fig. 4). The highest concentration of $\mathrm{Ca}^{2+}$ in precipitation mainly contributed by local and transported dust (Satyanarayana et al., 2010; Budhavan et al., 2011; Balestrini et al., 2014; Bisht et al., 2017; Khan et al., 2018), from the suspended soil (Rahn et al., 1976; Kulshrestha and Kumar et al., 2014) and from vehicular emission, cement factory etc. (Sanusi et al., 1996).

In the present study, we observed high concentration of both $\mathrm{Ca}^{2+}$ and $\mathrm{HCO}_{3}^{-}$at Leh and Beerwah site. It was mainly due to the influence of natural dust particles enriched with carbonate and bicarbonates of calcium (Kulshrestha et al., 1996; Cong et al., 2007; Li et al., 2007). Similar results were also reported in various studies in the Himalayan region

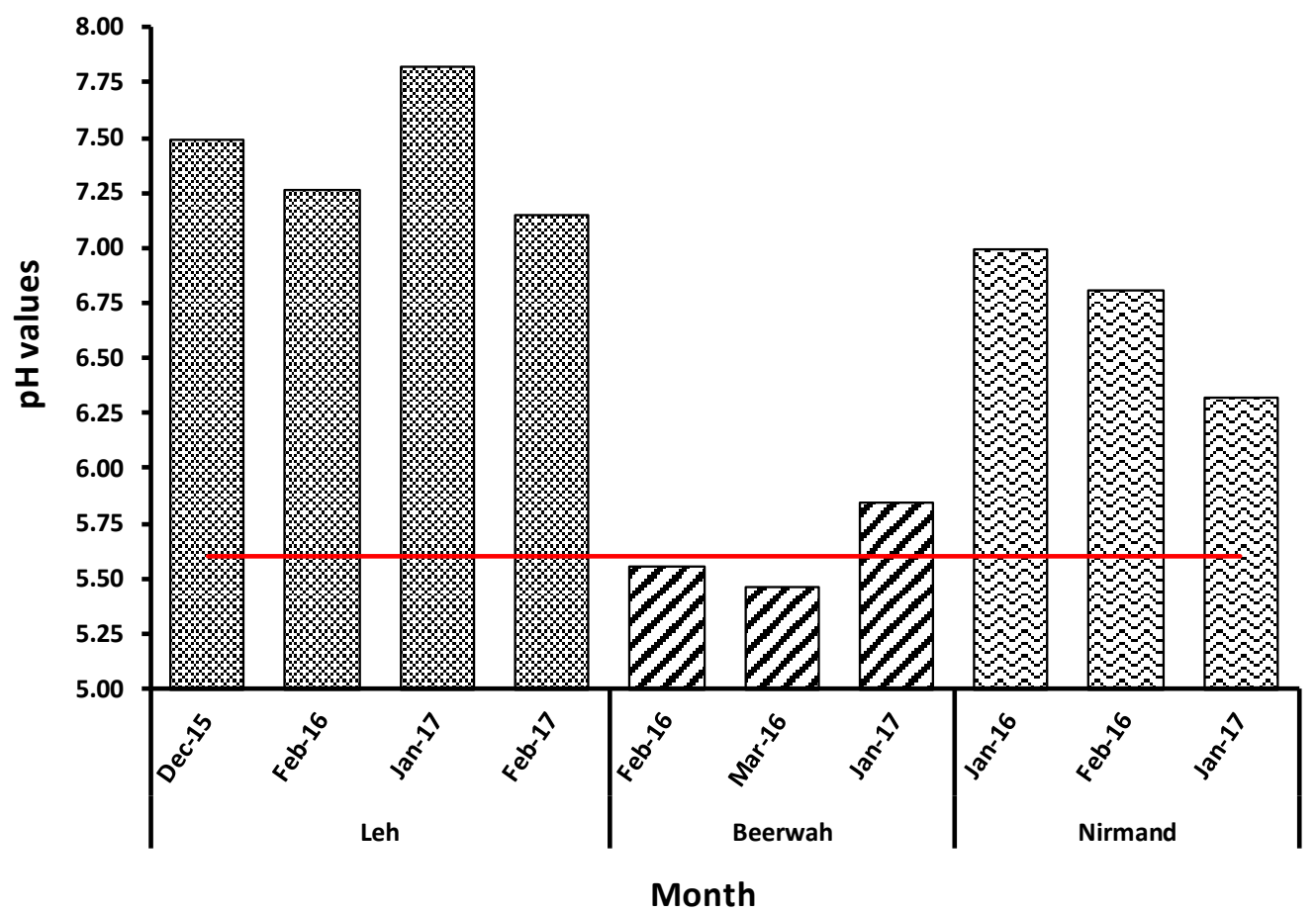

Fig. 2. Monthly average $\mathrm{pH}$ variation of snow at different sites of Himalayas. Note Red line indicates the neutral cloud water $\mathrm{pH}$. 
Table 1. Average concentrations $\left(\mu \mathrm{eq} \mathrm{L}^{-1}\right)$ of measured ionic species, $\mathrm{pH}$ and conductivity in snow sample at three different locations (Leh, Beerwah and Nirmand) in Western Himalaya of India along with minimum (Min.) and maximum (Max.) during 2015-2017.

\begin{tabular}{|c|c|c|c|c|c|c|c|c|c|}
\hline & \multicolumn{3}{|c|}{ Leh } & \multicolumn{3}{|c|}{ Beerwah } & \multicolumn{3}{|c|}{ Nirmand } \\
\hline & Min & Avg & Max & Min & Avg & Max & Min & Avg & Max \\
\hline $\mathrm{pH}$ & 7.02 & 7.48 & 8.11 & 5.18 & 5.80 & 6.47 & 5.30 & 6.39 & 7.09 \\
\hline $\mathrm{EC}$ & 7.78 & 44.40 & 109.20 & 0.25 & 9.01 & 25.00 & 2.04 & 96.24 & 530.00 \\
\hline $\mathrm{Na}^{+}$ & 0.48 & 24.14 & 73.91 & 1.01 & 17.80 & 57.83 & 1.66 & 35.36 & 372.23 \\
\hline $\mathrm{NH}_{4}{ }^{+}$ & 6.27 & 28.77 & 96.67 & 9.04 & 26.36 & 63.33 & 0.24 & 112.44 & 614.37 \\
\hline $\mathrm{K}^{+}$ & 0.15 & 17.40 & 53.85 & 0.53 & 15.64 & 53.59 & 0.35 & 27.15 & 113.36 \\
\hline $\mathrm{Ca}^{2+}$ & 17.66 & 74.34 & 220.16 & 5.57 & 40.66 & 131.50 & 34.50 & 53.05 & 84.00 \\
\hline $\mathrm{Mg}^{2+}$ & 7.14 & 33.49 & 70.61 & 0.66 & 21.17 & 90.53 & 0.19 & 12.62 & 51.03 \\
\hline $\mathrm{F}^{-}$ & 0.07 & 2.74 & 21.05 & 0.09 & 1.93 & 10.00 & 1.58 & 8.24 & 39.47 \\
\hline $\mathrm{Cl}^{-}$ & 2.13 & 23.72 & 49.15 & 2.54 & 20.39 & 50.85 & 0.80 & 67.71 & 343.75 \\
\hline $\mathrm{NO}_{3}^{-}$ & 0.22 & 14.62 & 25.48 & 0.31 & 11.36 & 27.41 & 0.11 & 7.02 & 27.42 \\
\hline $\mathrm{SO}_{4}{ }^{2-}$ & 0.80 & 19.70 & 40.63 & 0.37 & 15.40 & 33.33 & 0.90 & 16.71 & 36.25 \\
\hline $\mathrm{HCO}_{3}{ }^{-}$ & 32.79 & 179.07 & 524.59 & 32.79 & 157.97 & 393.44 & 32.79 & 163.93 & 262.30 \\
\hline
\end{tabular}
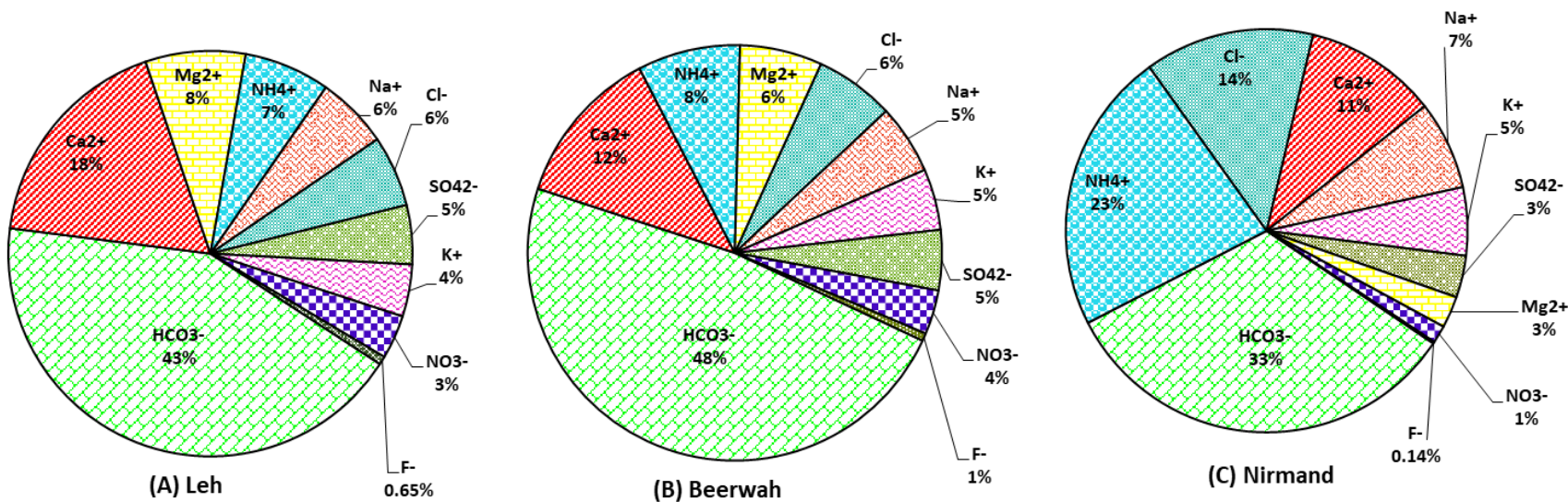

Fig. 3. The percentage contribution of individual cations and anions in snow samples at all sites.
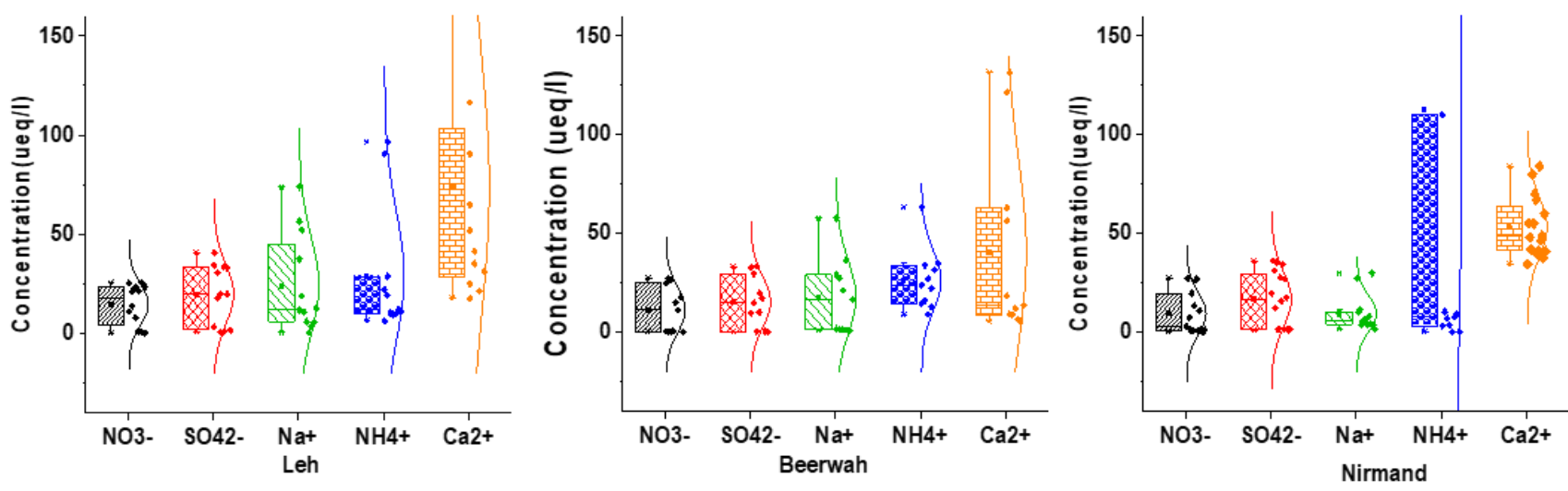

Fig. 4. Distributions of analyzed water-soluble ionic species at the three sampling sites in Himalayan region. The box plots along with box normal distribution indicate the mean (solid rectangular box within box) and median (solid line within box) distributions and the $90^{\text {th }}, 75^{\text {th }}, 25^{\text {th }}$, and $10^{\text {th }}$ percentiles.

(Huang et al., 2012; Zhang et al., 2012; Balestrini et al., 2014; Kumar et al., 2015). After $\mathrm{Ca}^{2+}$ and $\mathrm{Mg}^{2+}, \mathrm{NH}_{4}{ }^{+}$ion has been the most abundant at Leh and Beerwah site, whereas at Nirmand site the average concentration of $\mathrm{NH}_{4}{ }^{+}$was highest among all the cations (Fig. 4). A high concentration of $\mathrm{NH}_{4}{ }^{+}$amongst major cations at Nirmand site suggested a significant influence of anthropogenic sources such as livestock, agricultural activities, human and animal excreta, (Galloway, 1995; Singh and Kulshrestha, 2012; Khan et al., 2018). Khan et al. (2018) suggested the nearby vegetation 
and agriculture farming may contribute to the raised concentration of biogenic $\mathrm{NH}_{4}{ }^{+}$. Other sources such as increased tourist activities could also be considered as a significant source for $\mathrm{NH}_{4}{ }^{+}$in this region nowadays. Among all the anions, $\mathrm{HCO}_{3}{ }^{-}$and $\mathrm{Cl}^{-}$was highest at all three sites. Similar results were observed at high altitude Himalayan stations (Kumar et al., 2015; Roy et al., 2016; Bisth et al., 2017). We have found the average $\mathrm{SO}_{4}{ }^{2-}$ concentration was higher than the $\mathrm{NO}_{3}{ }^{-}$concentration at all the three sites (Fig. 4). Similar results were reported by (Zhang et al., 2012; Tiwari et al., 2012; Liu et al., 2013; Balestrini et al., 2014; Roy et al., 2016; Bisht et al., 2017) over Himalayan region. The high concentration of $\mathrm{SO}_{4}{ }^{2-}$ could be attributed to the anthropogenic sources which emit $\mathrm{SO}_{2}$. Since industrial activities were found to be lacking at all these sites, the maximum contribution to $\mathrm{SO}_{4}{ }^{2-}$ from the LRT and trans-boundary transport of other regions as well as the local influence of diesel driven vehicular emissions cannot be ruled out. $\mathrm{NO}_{3}{ }^{-}$concentrations were very low at all the three sites. In snow samples, high concentrations of $\mathrm{NO}_{3}{ }^{-}$could be attributed to their primary emissions as $\mathrm{NO}_{\mathrm{x}}$ from the increased vehicular activities that are eventually transformed to water-soluble $\mathrm{NO}_{3}{ }^{-}$species in the atmosphere (FinlaysonPitts and Pitts, 1986). Other than vehicular emissions, biomass burning by locals to produce heat during winters could be another regional factor (Singh et al., 2014). Apart from regional emissions, long-range transport of $\mathrm{NO}_{\mathrm{x}} / \mathrm{NO}_{3}{ }^{-}$ by various air masses approaching the sampling sites could be attributed to a high concentration of $\mathrm{NO}_{3}{ }^{-}$. At all the three sites concentration of carbonate was found to be very high in snow samples due to the contribution of soil dust comprising high fractions of $\mathrm{CaCO}_{3}, \mathrm{MgCO}_{3}$, and $\mathrm{MgSO}_{4}$.

\section{Wet Deposition Fluxes Through Snow Fall Deposition}

Table 2 represents the average wet deposition fluxes for all the samples collected during the winter and spring seasons. From the table, it is very clear that the average wet deposition fluxes at Leh was in the order like- $\mathrm{HCO}_{3}^{-}>\mathrm{Ca}^{2+}>\mathrm{Mg}^{2+}>$ $\mathrm{NH}_{4}{ }^{+}>\mathrm{Na}^{+}=\mathrm{Cl}^{-}>\mathrm{SO}_{4}{ }^{2-}>\mathrm{K}^{+}>\mathrm{NO}_{3}{ }^{-}>\mathrm{F}^{-}$and at Beerwah followed the order- $\mathrm{HCO}_{3}{ }^{-}>\mathrm{Ca}^{2+}>\mathrm{NH}_{4}{ }^{+}>\mathrm{Mg}^{2+}>\mathrm{Cl}^{-}>$ $\mathrm{Na}^{+}>\mathrm{K}^{+}>\mathrm{SO}_{4}{ }^{2-}>\mathrm{NO}_{3}{ }^{-}>\mathrm{F}^{-}$while at Nirmand site it is like $\mathrm{HCO}_{3}{ }^{-}>\mathrm{NH}_{4}{ }^{+}>\mathrm{Cl}^{-}>\mathrm{Ca}^{2+}>\mathrm{Na}^{+}>\mathrm{K}^{+}>\mathrm{S} \mathrm{O}_{4}{ }^{2-}>\mathrm{Mg}^{2+}>$ $\mathrm{F}^{-}>\mathrm{NO}_{3}^{-}$. At Leh and Beerwah, the highest value of wet deposition fluxes was recorded for $\mathrm{HCO}_{3}{ }^{-}$and $\mathrm{Ca}^{2+}$ which may

Table 2. Average wet deposition fluxes during winter and spring seasons $\left(\right.$ meq $\mathrm{m}^{-2}$ ).

\begin{tabular}{llll}
\hline Ions & Leh & Beerwah & Nirmand \\
\hline $\mathrm{Na}^{+}$ & 13 & 21 & 42 \\
$\mathrm{NH}_{4}{ }^{+}$ & 15 & 31 & 132 \\
$\mathrm{~K}^{+}$ & 9 & 18 & 32 \\
$\mathrm{Ca}^{2+}$ & 40 & 48 & 62 \\
$\mathrm{Mg}^{2+}$ & 18 & 25 & 15 \\
$\mathrm{~F}^{-}$ & 1 & 2 & 10 \\
$\mathrm{Cl}^{-}$ & 13 & 24 & 80 \\
$\mathrm{NO}_{3}{ }^{-}$ & 8 & 13 & 8 \\
$\mathrm{SO}_{4}{ }^{2-}$ & 11 & 18 & 20 \\
$\mathrm{HCO}_{3}{ }^{-}$ & 96 & 186 & 193 \\
\hline
\end{tabular}

be due to crustal influence (Jain et al., 2000; Kulshrestha et al., 2003). Whereas at Nirmand site maximum wet deposition fluxes were recorded for $\mathrm{HCO}_{3}{ }^{-}$and for $\mathrm{NH}_{4}{ }^{+}$suggested anthropogenic activity in this region. Elevated deposition fluxes for $\mathrm{Na}^{+}$and $\mathrm{Cl}^{-}$might be due to marine aerosols deposited at all sites. Acidic species like $\mathrm{SO}_{4}{ }^{2-}$ and $\mathrm{NO}_{3}{ }^{-}$are lesser in comparison to $\mathrm{Ca}^{2+}$ suggesting alkaline nature of precipitation, which is very common in the Indian region.

\section{Source Apportionment}

For assessing the role of source categories and their percentage contribution, the results were further evaluated with marine and non-marine fractions. Non marine fractions were estimated for their crustal and anthropogenic fractions using the approach reported by Kulshrestha et al. (1997).

\section{Marine Contribution}

The sea salt fraction(ssf) and non-sea salt fractions (nssf) of viz. $\mathrm{Cl}^{-}, \mathrm{SO}_{4}{ }^{2-}, \mathrm{K}^{+}, \mathrm{Mg}^{2+}$, and $\mathrm{Ca}^{2+}$ were calculated and presented in Table 3. At Leh and Beerwah sites, the ratios of $\mathrm{SO}_{4}{ }^{2-}, \mathrm{K}^{+}, \mathrm{Ca}^{2+}, \mathrm{Mg}^{2+}$ were found to be higher than that of seawater. Similar results were also found by Kumar and coworkers (2015) at Mukhteshwar site of Kullu Distrct. However, at Nirmand site, the ratios of $\mathrm{Cl}^{-}, \mathrm{SO}_{4}{ }^{2-}, \mathrm{K}^{+}$, and $\mathrm{Ca}^{2+}$ were found to be more than that of seawater, which indicates that crustal (soil dust) and anthropogenic influence of these ions are in the snow over the western Himalayas in India. At all the sites, the results showed that $\mathrm{Cl}^{-} / \mathrm{Na}^{+}$ratio was very close to seawater ratios representing its major contribution from marine sources. In Indian region, higher ratios of $\mathrm{SO}_{4}{ }^{2-} / \mathrm{Na}^{+}, \mathrm{K}^{+} / \mathrm{Na}^{+}$, and $\mathrm{Ca}^{2+} / \mathrm{Na}^{+}$in precipitation have been reported at various sites (Kulshrestha et al., 2003; Safai et al., 2004; Tiwari et al., 2007; Bisht et al., 2015). Ali et al. (2004) revealed that the compounds containing $\mathrm{Ca}^{2+}$, $\mathrm{Mg}^{2+}$, and $\mathrm{K}^{+}$are incorporated into the atmosphere by the erosion of soil in the form of their carbonate salts. The nssf of $\mathrm{SO}_{4}{ }^{2-}, \mathrm{K}^{+}, \mathrm{Mg}^{2+}$, and $\mathrm{Ca}^{2+}$ confirms the dominance of crustal and anthropogenic sources of $\mathrm{Ca}^{2+}, \mathrm{K}^{+}, \mathrm{Mg}^{2+}$, and $\mathrm{SO}_{4}{ }^{2-}$. The similar results have also been reported by various studies on the snow chemistry (Keene et al., 1986; Naik et al., 1995; Zhu et al., 2012; Niu et al., 2013; Kumar et al., 2015).

\section{Non-marine Contribution}

Table 4 shows the percent contribution of crustal fractions (CF) and anthropogenic fractions (Anthro) of each ionic species of snowfall species. As shown in Table 4, all the three sites have maximum $\mathrm{Ca}^{2+}$ contribution, which is associated with the crustal fraction. A similar result was found at a different site of the Himalayan region by Kumar et al. (2015, 2016). Some researchers have suggested that $\mathrm{nssCa}^{2+}$ in snow samples is due to transported dust at Himalaya and Tibetan Plateau (Mayewski et al., 1983; Kumar et al., 2015, 2016).

The percent contribution of $\mathrm{NO}_{3}{ }^{-}$and $\mathrm{NH}_{4}{ }^{+}$were found to be higher in anthropogenic in comparison to crustal fraction. At all the three sites, very high fraction of anthropogenic $\mathrm{NO}_{3}{ }^{-}$was observed. Previous studies also reported $\mathrm{NO}_{3}{ }^{-}$is mostly of anthropogenic in nature (Das et al., 2005; Singh et al., 2007; Budhavant et al., 2009; Tiwari et al., 2012; Bisht et al., 2015; Roy et al., 2016; Bisht et al., 2017). In 
Table 3. Equivalent concentration ratios of ionic components with respect to Sodium.

\begin{tabular}{lllllll}
\hline Site & Ions & Sea Water* & Snow Melt & EF & ssf\% & nsf\% \\
\hline Leh & $\mathrm{Cl}-$ & 1.16 & 0.98 & 0.85 & 118.05 & 0.00 \\
& $\mathrm{SO}_{4}{ }^{2-}$ & 0.13 & 0.82 & 6.53 & 15.32 & 84.68 \\
& $\mathrm{~K}^{+}$ & 0.02 & 0.72 & 32.76 & 3.05 & 96.95 \\
& $\mathrm{Ca}^{2+}$ & 0.04 & 3.08 & 69.99 & 1.43 & 98.57 \\
\multirow{5}{*}{ Beerwah } & $\mathrm{Mg}^{2+}$ & 0.23 & 1.39 & 6.31 & 15.86 & 84.14 \\
& $\mathrm{Cl}^{-}$ & 1.16 & 1.09 & 0.94 & 106.15 & 0.00 \\
& $\mathrm{SO}^{2-}$ & 0.13 & 0.87 & 6.93 & 14.44 & 85.56 \\
& $\mathrm{~K}^{+}$ & 0.02 & 0.88 & 39.94 & 2.50 & 97.50 \\
& $\mathrm{Ca}^{2+}$ & 0.04 & 2.29 & 51.96 & 1.92 & 98.08 \\
& $\mathrm{Mg}^{2+}$ & 0.23 & 1.19 & 5.41 & 18.50 & 81.50 \\
& $\mathrm{Cl}^{-}$ & 1.16 & 1.92 & 1.65 & 60.56 & 39.44 \\
& $\mathrm{SO}^{2-}$ & 0.13 & 0.47 & 3.78 & 26.45 & 73.55 \\
& $\mathrm{~K}^{+}$ & 0.02 & 0.77 & 34.90 & 2.87 & 97.13 \\
& $\mathrm{Ca}^{2+}$ & 0.04 & 1.50 & 34.10 & 2.93 & 97.07 \\
\hline
\end{tabular}

Table 4. The percent contribution of marine fractions, crustal fractions (CF) and anthropogenic fractions (Anthro) of each ionic species.

\begin{tabular}{|c|c|c|c|c|c|c|c|c|c|}
\hline \multirow{3}{*}{ Ions } & \multicolumn{3}{|c|}{ LEH } & \multicolumn{3}{|c|}{ BEERWAH } & \multicolumn{3}{|c|}{ NIRMAND } \\
\hline & \multirow{2}{*}{$\begin{array}{l}\text { ssf } \\
\text { Marine }\end{array}$} & \multicolumn{2}{|r|}{ nssf } & \multirow{2}{*}{$\begin{array}{l}\text { ssf } \\
\text { Marine }\end{array}$} & \multicolumn{2}{|r|}{ nssf } & \multirow{2}{*}{$\begin{array}{l}\text { ssf } \\
\text { Marine }\end{array}$} & \multicolumn{2}{|r|}{ nssf } \\
\hline & & $\mathrm{CF}$ & Anthropogenic & & $\mathrm{CF}$ & Anthropogenic & & $\mathrm{CF}$ & Anthropogenic \\
\hline $\mathrm{Cl}^{-}$ & 100 & 0 & 0 & 100 & 0 & 0 & 61 & 39 & 0 \\
\hline $\mathrm{F}^{-}$ & 0 & 1 & 99 & 0 & 2 & 98 & 0 & 1 & 99 \\
\hline $\mathrm{NO}_{3}^{-}$ & 0 & 31 & 69 & 0 & 22 & 78 & 0 & 29 & 71 \\
\hline $\mathrm{SO}_{4}{ }^{2-}$ & 15 & 66 & 19 & 15 & 45 & 40 & 26 & 74 & 0 \\
\hline $\mathrm{K}^{+}$ & 3 & 97 & 0 & 3 & 72 & 25 & 3 & 43 & 54 \\
\hline $\mathrm{Ca}^{2+}$ & 1 & 99 & 0 & 2 & 98 & 0 & 3 & 97 & 0 \\
\hline $\mathrm{Mg}^{2+}$ & 16 & 68 & 16 & 19 & 81 & 0 & 62 & 38 & 0 \\
\hline $\mathrm{Na}^{+}$ & 100 & 0 & 0 & 100 & 0 & 0 & 100 & 0 & 0 \\
\hline $\mathrm{NH}_{4}^{+}$ & 0 & 7 & 93 & 0 & 4 & 96 & 0 & 2 & 98 \\
\hline
\end{tabular}

global precipitation, $\mathrm{NO}_{3}{ }^{-}$has also been reported in airmass trajectories due to long-range transport (Avila and Alacron, 1999; Satyanarayana et al., 2010).

The $\mathrm{nsSSO}_{4}{ }^{2-}$, at Beerwah and Leh site showed the higher percentage contribution of Anthropogenic $\mathrm{SO}_{4}{ }^{2}$. This might be due to fossil fuel combustion at the origin of airmasses as well as during the transport of airmasses before reaching the site. Apart from LTR, the contribution from local sources such as the use of generators which are mostly operated on diesel cannot be ruled out. The presence of anthropogenic $\mathrm{SO}_{4}{ }^{2-}$ in the form of $\left(\mathrm{NH}_{4}\right)_{2} \mathrm{SO}_{4}$ and $\mathrm{NH}_{4} \mathrm{HSO}_{4}$ has been reported in precipitation worldwide (Finlayson-Pitts and Pitts, 1986; Kulshrestha et al., 2003). At Leh and Nirmand site the crustal fraction of $\mathrm{SO}_{4}{ }^{2-}$ was very high than that of anthropogenic form. This high crustal $\mathrm{SO}_{4}{ }^{2-}$ at both the sites may be due to $\mathrm{SO}_{2}$ adsorption onto $\mathrm{Ca}^{2+}$ rich dust particles as it scavenges acidic precursor (Kulshrestha et al., 2003b; Kulshrestha, 2013), which is very common in India. The maximum percentage fraction of $\mathrm{nssK}^{+}$is contributed by crustal sources at Leh and Beerwah sites. Sometimes local soils contain a very high level of potassium (Jain et al., 2000). But at Nirmand site $n \mathrm{sSK}^{+}$mainly contributed by anthropogenic sources. At this rural site biomass burning is the main reason for high $\mathrm{nssK}^{+}$by anthropogenic sources.
Apart from biomass burning, $\mathrm{nssK}^{+}$due to crustal sources have been reported in precipitation (Zhang et al., 2007). Besides marine origin, $\mathrm{Mg}^{2+}$ is also contributed by crustal sources at all three sites. $\mathrm{Mg}^{2+}$ has been reported in snow samples due to a significant contribution from crustal sources (Kang et al., 2004).

The average percent contribution of marine, crustal, and anthropogenic sources was calculated and showed in Fig. 5. The order of dominance followed the sequence- at Leh: Crustal $(56 \%)>$ Marine $(24 \%)>$ Anthropogenic $(20 \%)$, at Beerwah: Crustal $(46 \%)>$ Marine $(27 \%)=$ Anthropogenic $(27 \%)$. The dominant contribution of crustal fraction in snow samples due to local as well as long range transport has been suggested by Shrestha et al. (2002) and Zhang et al. (2013). After crustal, the contribution of the marine fraction is dominated over anthropogenic. A similar result was observed by Kumar and co-workers in snow at different sites of Himalayas (Kumar et al., 2015, 2016). The $\mathrm{pH}$ of snow samples at both sites also suggested a significant contribution of crustal components, i.e., alkaline species over anthropogenic components, i.e., acidic species whereas seasalt fraction does not play an important role in controlling the $\mathrm{pH}$ of precipitation samples. At the Nirmand site the contribution from sources followed the sequence- Anthropogenic (40\%) > Crustal $(33 \%)>$ Marine 


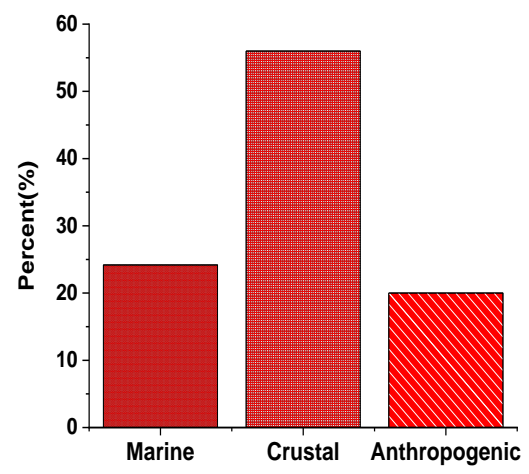

(A) Leh

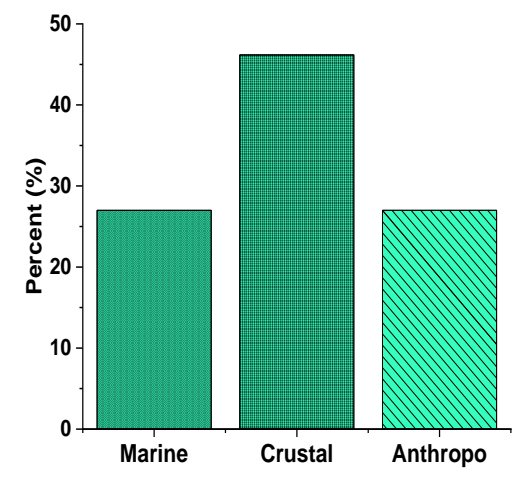

(B) B eerwah

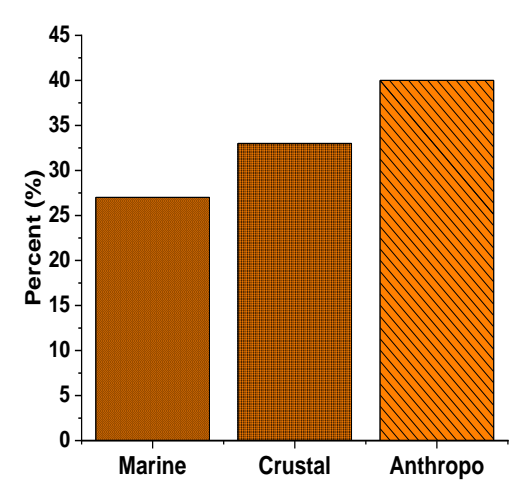

(C) Nirmand

Fig. 5. Marine, crustal and anthropogenic fraction at all sites.

(27\%). At this mainly activities are biomass burning, agriculture, suggested pollution coming from this contribute to anthropogenic sources. The $\mathrm{pH}$ of this site and the results of ions suggested complete neutralization of $\left(\mathrm{SO}_{4}{ }^{2-}\right)$ by $\mathrm{NH}_{4}{ }^{+}$to form $\left(\mathrm{NH}_{4}\right)_{2} \mathrm{SO}_{4} \& \mathrm{NH}_{4} \mathrm{HSO}_{4}$ and $\mathrm{CaCO}_{3}$ rich dust particles forming calcium sulphate.

Three-days back trajectory analysis was also performed (Figs. 6(a)-6(c)) for the confirmation of the possible sources of pollutants over the Himalayan region. Backward airmass trajectories for $72 \mathrm{~h}$ of $2000 \mathrm{~m}$ above ground level were calculated using the geographic information system (GIS) based software, TrajStatfor all snowfall samples (Wang et al., 2009).

Mostly westerly air masses prevailed during the study. The air mass trajectories at Leh site show that the North Atlantic Ocean, Africa, Europe, Middle East, China, and Mediterranean region are the sources which contribute through the long-range transport of pollutants (Fig. 6(a)). At Beerwah site, the airmasses arrived from Africa, Europe, Pakistan, Kazakhstan, Afganistan and Middle-East along with Punjab, Haryana, Delhi, Uttar Pradesh (Fig. 6(b)). Both the LRT and the local sources are responsible for deposition of pollutants in snow at this site. At the Nirmand site, the airmasses mainly approached from Africa, China, Pakistan, Uzbekistan, Tazakistan along with Punjab, Haryana, Delhi, Uttar Pradesh, Madhya- Pradesh, Maharastra (Fig. 6(c)).

\section{Statistical Approach for Source Identification}

Statistical analysis is also used to identify the relationship between major ions in snow samples and their possible sources. For, the estimates of correlation coefficients, the graph were plotted between the water-soluble ions in snow samples in Figs. 7(a)-7(c) for the respective sites. A good correlation between $\mathrm{SO}_{4}{ }^{2-}$ and $\mathrm{NO}_{3}{ }^{-}$in snow samples at all the site suggesting the origin of these ions from the similar sources such as combustion of fossil fuel in which $\mathrm{SO}_{2}$ and $\mathrm{NO}_{\mathrm{x}}$ are emitted that eventually get oxidised into $\mathrm{SO}_{4}{ }^{2-}$ and $\mathrm{NO}_{3}{ }^{-}$(Kulshrestha et al., 2005; Kumar et al., 2016). A strong correlation between major sea salt components such as $\mathrm{Na}^{+}$ and $\mathrm{Cl}^{-}$at all the sites indicative of their origin from marine source. Similarly, a good correlation is observed between ions such as $\mathrm{Ca}^{2+}$ and $\mathrm{SO}_{4}{ }^{2-}$ at all sites, $\mathrm{Ca}^{2+}$ and $\mathrm{Mg}^{2+}$ at
Beerwah and Nirmand site, $\mathrm{Mg}^{2+}$ and $\mathrm{SO}_{4}{ }^{2-}$ at Beerwah site. It might be due to the chemical interactions between crustal components rich in $\mathrm{Ca}^{2+}$ and $\mathrm{Mg}^{2+}$ with the acids such as $\mathrm{H}_{2} \mathrm{SO}_{4}$ and $\mathrm{HNO}_{3}$ in precipitation. These reactions enhance the alkalinity of precipitation and decrease the acidity of snow samples interestingly $\mathrm{SO}_{4}{ }^{2-}$ and $\mathrm{NO}_{3}{ }^{-}$showed good correlation with $\mathrm{NH}_{4}{ }^{+}$derived from anthropogenic activities as well as with crustal components such as $\mathrm{Ca}^{2+}$ and $\mathrm{Mg}^{2+}$. The strong correlation suggested the chemical reaction between these ion said in the stoichiometric neutralization of the acidic moieties present in the snow melt. The formation of $\mathrm{NH}_{4}, \mathrm{SO}_{4},\left(\mathrm{NH}_{4}\right)_{2} \mathrm{SO}_{4}$ and $\mathrm{NH}_{4} \mathrm{NO}_{3}$ in precipitation samples have been reported due to reaction of ammonia in the atmosphere with $\mathrm{H}_{2} \mathrm{SO}_{4}$ and $\mathrm{HNO}_{3}$ (Kulshrestha et al., 2005; Seinfield and Pandis, 2006).

\section{Source Identification of Ions Using Principal Component Analysis}

The principal component analysis (PCA) was attempted using snow chemistry data to identify the processes and emission sources of water-soluble ions in snow. Table 5 presents PCA results with varimax rotation. At Leh site, PC the total variance and showed high loading for $\mathrm{F}^{-}, \mathrm{Na}^{+}, \mathrm{Ca}^{2+}$ and $\mathrm{Mg}^{2+}$ clearly reflecting their origin from crustal sources. PC2 explains $22.38 \%$ of variance had a high loading of $\mathrm{Na}^{+}$ and $\mathrm{NH}_{4}{ }^{+} . \mathrm{Na}^{+}$mainly comes from sea salt and also derived from soil, whereas $\mathrm{NH}_{4}{ }^{+}$, indicating its unique anthropogenic source from volatilization of animal manure, human excreta and agricultural activities. The PC3 contained $\mathrm{K}^{+}$with $15.32 \%$ of the total variance, may be linked with biomass burning. PC4 explains $11.76 \%$ of the total variance and due to high loading of $\mathrm{NO}_{3}{ }^{-}$, could be vehicular emissions.

At Beerwah site, three components that were extracted may be attributed to three different sources. PC1 explained the $40.33 \%$ of the total variance and was found to be loaded with $\mathrm{NH}_{4}{ }^{+}, \mathrm{Na}^{+}, \mathrm{K}^{+}, \mathrm{Cl}^{-}, \mathrm{NO}_{3}{ }^{-}$and $\mathrm{SO}_{4}{ }^{2-}$ indicating the influence of secondary inorganic aerosol from the anthropogenic sources. This factor can be attributed to regional pollution arising from coal-burning activities $\left(\mathrm{Na}^{+}, \mathrm{K}^{+}, \mathrm{Cl}^{-}, \mathrm{SO}_{4}^{2-}\right)$ and agricultural practices $\left(\mathrm{NH}_{4}^{+}\right)$. $\mathrm{PC} 2$ was loaded with $\mathrm{Ca}^{2+}$ and $\mathrm{Mg}^{2+}$ and explained the $18.38 \%$ of the total variance. Loading of these variables in second factor suggests the influence of 
Airmass Back Trajectory_Leh
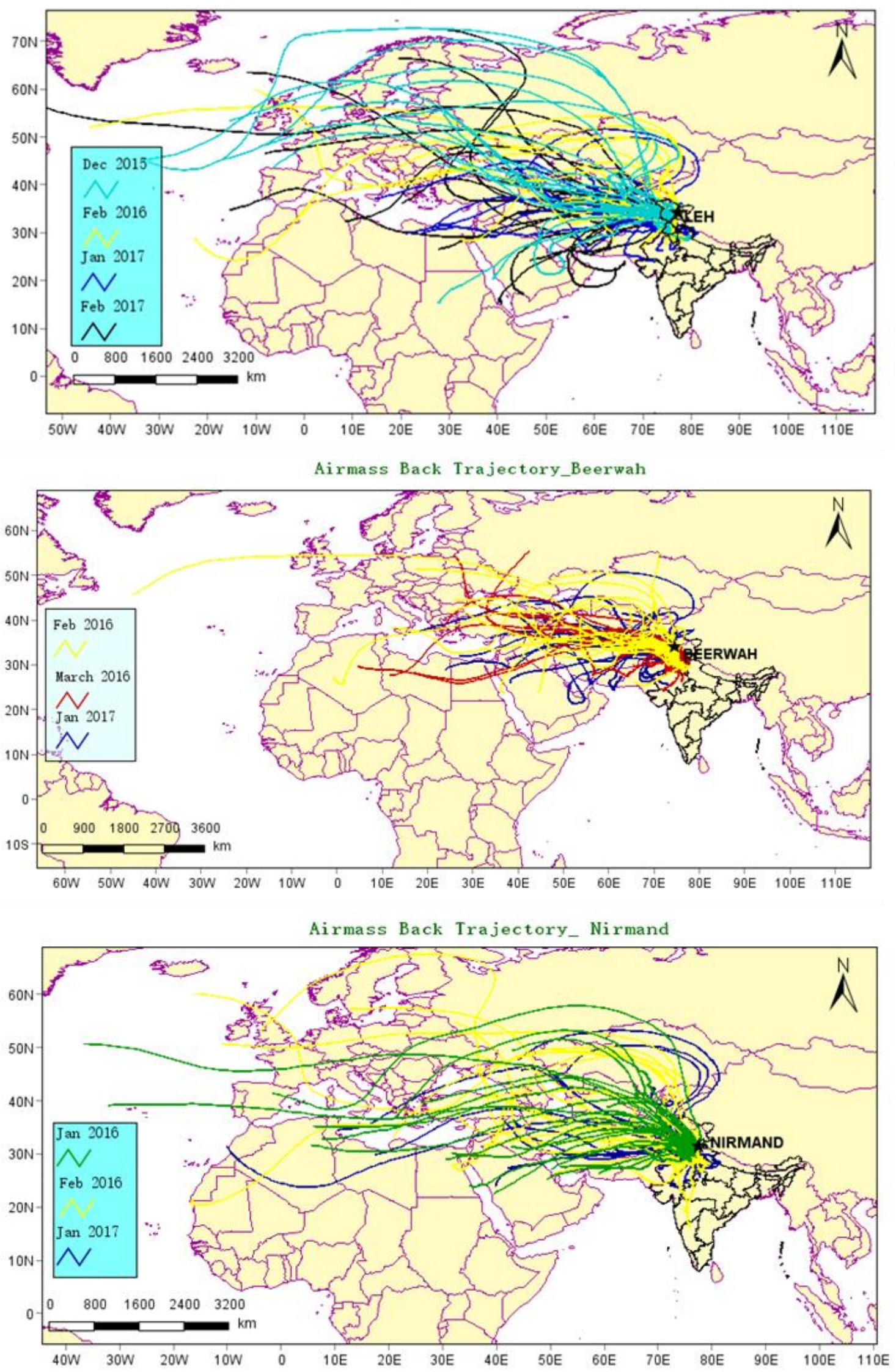

Fig. 6. Airmass back trajectory at Leh, Beerwah and Nirmand respectively. 


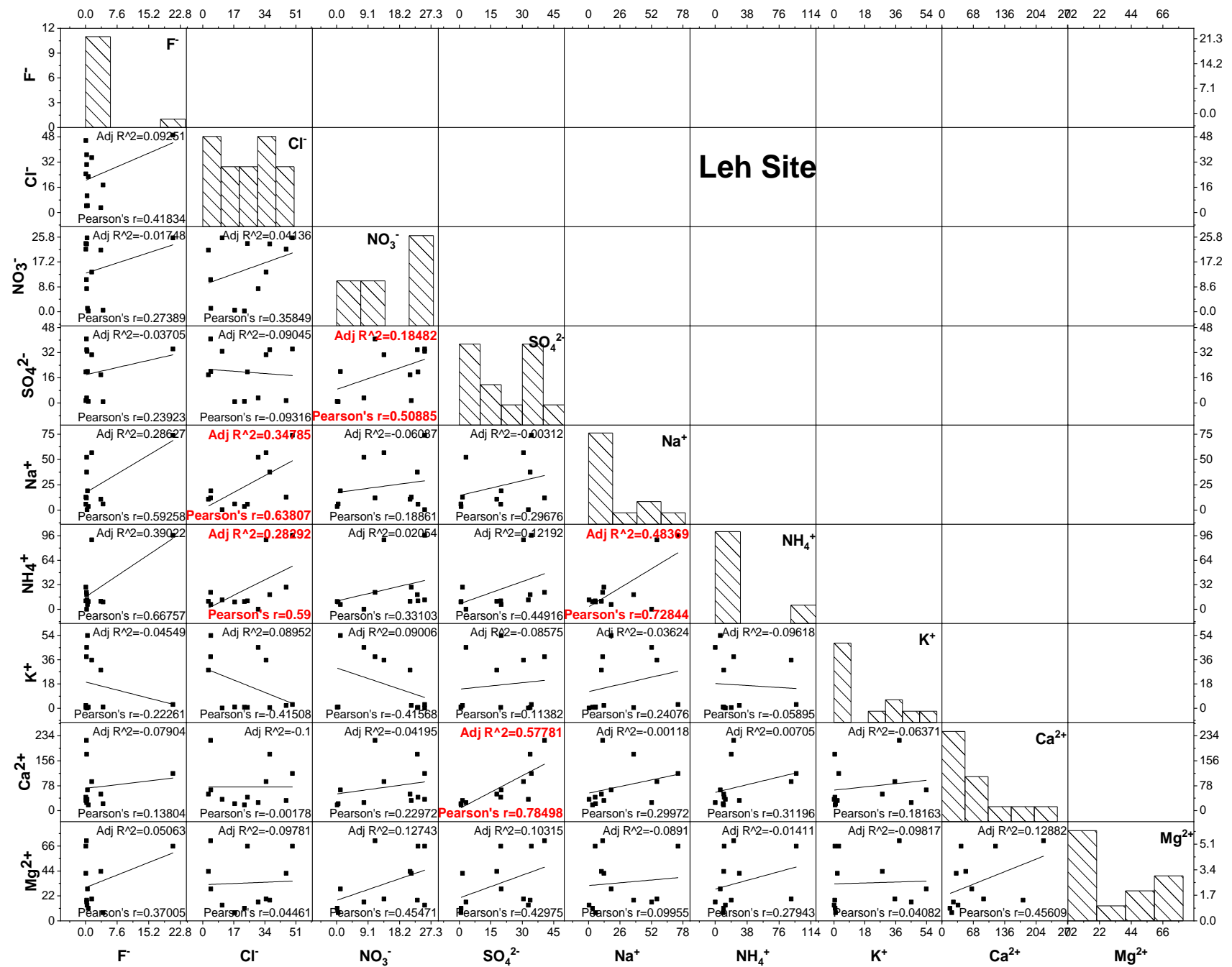

Fig. 7(a). Correlation matrix and frequency distribution graphs of water soluble ions in snowmelt at Leh site.

crustal and windblown soil dust. PC3 explained $14.02 \%$ of the variance and found to be loaded with $\mathrm{K}^{+}$and $\mathrm{F}^{-}$. Presence of $\mathrm{K}^{+}$, and $\mathrm{F}^{-}$variables indicate the influence of biomass burning sources over the studied area.

At Nirmand site, PC 1 showed high loading of $\mathrm{NH}_{4}^{+}, \mathrm{K}^{+}$, $\mathrm{Na}^{+}$and $\mathrm{Cl}^{-}$with total variance of $34.91 \%$. $\mathrm{Na}^{+}$and $\mathrm{Cl}^{-}$ suggested the contribution from salty soil profile in the region and longrange transport of sea winds. $\mathrm{K}^{+}$and $\mathrm{NH}_{4}{ }^{+}$ are tracer of biomass burning which includes domestic burning of firewood and agricultural residues. This PC represents a combination of coal and biomass burning. PC2 showed high loading of $\mathrm{NH}_{4}{ }^{+}, \mathrm{NO}_{3}{ }^{-}$, and $\mathrm{SO}_{4}{ }^{2-}$ with a total variance of $26.14 \%$. These ions are secondary in origin and formed by chemical reactions in the atmosphere of ammonium sulfate and ammonium nitrate. PC3 showed high loading of $\mathrm{Mg}^{2+}$ and $\mathrm{Ca}^{2+}$ with a total variance of $17.48 \%$. Theses ions are typically associated with crustal materials in windblown dust, resuspended dust, and dust from paved and unpaved roads.

Therefore, the overall conclusion could be inferred from both the statistical approach viz. correlation matrix and PCA that at Leh site $\mathrm{Ca}^{2+}$ and $\mathrm{Mg}^{2+}$ have strong correlation and PCA suggested they have common sources mainly coming from crustal sources. At Beerwah $\mathrm{Na}^{+}, \mathrm{K}^{+}, \mathrm{Cl}^{-}, \mathrm{SO}_{4}{ }^{2-}$ and $\mathrm{NH}_{4}{ }^{+}$are major source of pollution suggested local burning, agriculture activities are dominant in this region. At Nirmad site correlation table shows $\mathrm{NH}_{4}^{+}, \mathrm{K}^{+}, \mathrm{NO}_{3}{ }^{-}, \mathrm{SO}_{4}{ }^{2-}$ have good correlation and PCA suggested they all are coming from anthropogenic sources.

\section{Acidification and Neutralization Potentials}

At Leh, the neutralization factor (NF) values of $\mathrm{Ca}^{2+}$, $\mathrm{NH}_{4}{ }^{+}$, and $\mathrm{Mg}^{2+}$ were estimated and found to be 2.34, 0.92, and 0.90 , respectively (Fig. 8). Beerwah site also showed a pattern of NF where the $\mathrm{NF}$ value of $\mathrm{Ca}^{2+}, \mathrm{NH}_{4}^{+}$, and $\mathrm{Mg}^{2+}$ was estimated and found to be $1.62,1.07$, and 0.70 , respectively. These results suggested that at both sites, maximum neutralization occurred by $\mathrm{Ca}^{2+}$ and $\mathrm{NH}_{4}{ }^{+}$in snow. Similar results were also observed by Kumar and co-workers in the snow at other sites of India, showing maximum neutralizing capacity for $\mathrm{Ca}^{2+}$ is about 1.65 at Mukhteshwar (Kumar et al., 2015) and 1.17 at Gulmarg (Kumar et al., 2016). The maximum neutralization by $\mathrm{Ca}^{2+}$ and $\mathrm{NH}_{4}^{+}$in precipitation has been reported by other workers worldwide (Kulshrestha et al., 2003; Zhang et al., 2007; Satyanarayana et al., 2010; Roy et al., 2017). 


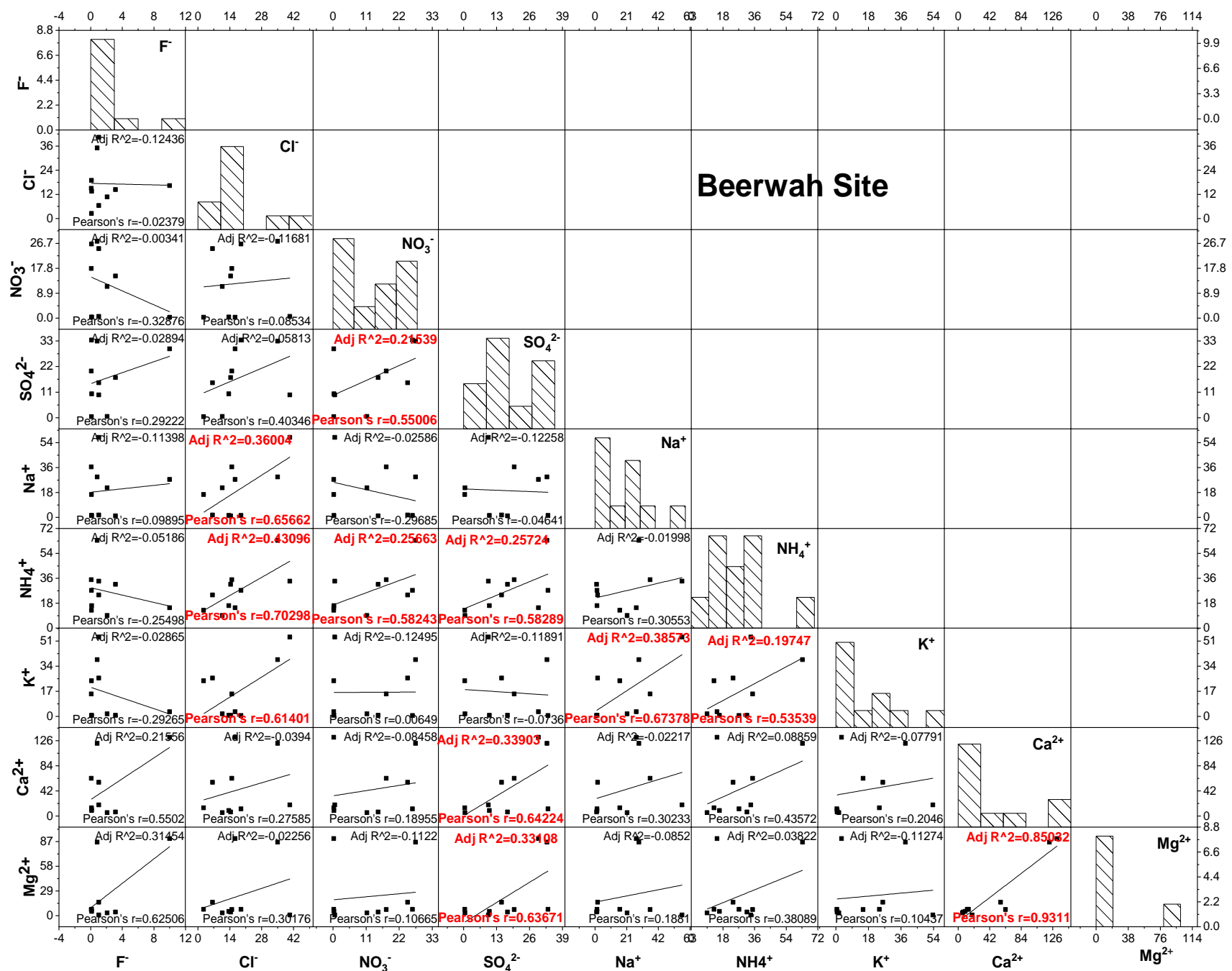

Fig. 7(b). Correlation matrix and frequency distribution graphs of soluble ions in snow at Beerwah site.

Kulshrestha et al. (1995) have suggested that neutralization by $\mathrm{Ca}^{2+}$ and $\mathrm{Mg}^{2+}$ done through a below-cloud process, whereas by $\mathrm{NH}_{4}{ }^{+}$done via an in-cloud process. Further, coarse mode aerosols predominantly contain $\mathrm{Ca}^{2+}$ and $\mathrm{Mg}^{2+}$ ions, and fine mode aerosols contain $\mathrm{NH}_{4}{ }^{+}$ion. Jain et al. (2000) suggested in, calcite-rich suspended dust neutralizes acidic component present in precipitation in India. At Nirmand site the NF values of $\mathrm{NH}_{4}^{+}, \mathrm{Ca}^{2+}$, and $\mathrm{Mg}^{2+}$ were estimated and found to be $5.15,2.35$ and 0.22 respectively, showing that $\mathrm{NH}_{4}{ }^{+}$neutralization dominant over $\mathrm{Ca}^{2+}$ at this site. The high concentration of $\mathrm{NH}_{4}{ }^{+}$was consistent with more $\mathrm{NH}_{3}$ sources found at this site, mainly emitted from biomass burning, fertilizer, and animal breeding (Bouwman et al., 1997). The higher $\mathrm{NF}$ of $\mathrm{NH}_{4}^{+}$than $\mathrm{Ca}^{2+}$ was also observed over a rural station near Bhubaneswar on the east coast of Bay of Bengal (Das et al., 2005; Das et al., 2010). Roy et al. (2017) also reported the same results at high altitude Himalayan stations in eastern India.

\section{CONCLUSION}

The mean $\mathrm{pH}$ of snow at Leh, Beerwah and Nirmand was
$74 \pm 0.38,5.77 \pm 0.35$ and $6.46 \pm 0.39$ respectively well above 5.60, which is the reference $\mathrm{pH}$ of snow and ranged between 5.18 and 8.11. During the study period, almost $60 \%$ of snow-water samples were found to be acidic in nature at Beerwah. Maximum pH was observed at Leh site, and the minimum was observed at Beerwah site. The average $\mathrm{pH}$ was higher at Leh (urban) and Nirmand (rural) then at Beerwah (semi-urban) due to the dominance of soil-derived particles. Overall the study revealed that basic ions largely control $\mathrm{pH}$ and acidity of snow water over the Himalayan region. The acidity in the snow is largely neutralized by $\mathrm{Ca}^{2+}$ at Leh and Beerwah site, whereas at Nirmand site it was neutralized by $\mathrm{NH}_{4}{ }^{+}$. The order of measured major cations $\mathrm{Ca}^{2+}>\mathrm{Mg}^{2+}>\mathrm{NH}_{4}{ }^{+}$at Leh and Beerwah, but at Nirmand $\mathrm{NH}_{4}{ }^{+}>\mathrm{Ca}^{2+}>\mathrm{Na}^{+}$. The dominant anion was $\mathrm{HCO}_{3}{ }^{-}$at all the sites. The major acidifying ion in snow was sulfate $\left(\mathrm{SO}_{4}{ }^{2-}\right)$, which was influenced by the long-range transport from the North Atlantic Ocean, Africa, Europe, the Middle East, and Mediterranean region. The high concentrations of cations were associated with depressions rich in calcite. Among the cations, $\mathrm{Ca}^{2+}$ makes the highest contribution at Leh and Beerwah sites, indicating the incorporation of soil 


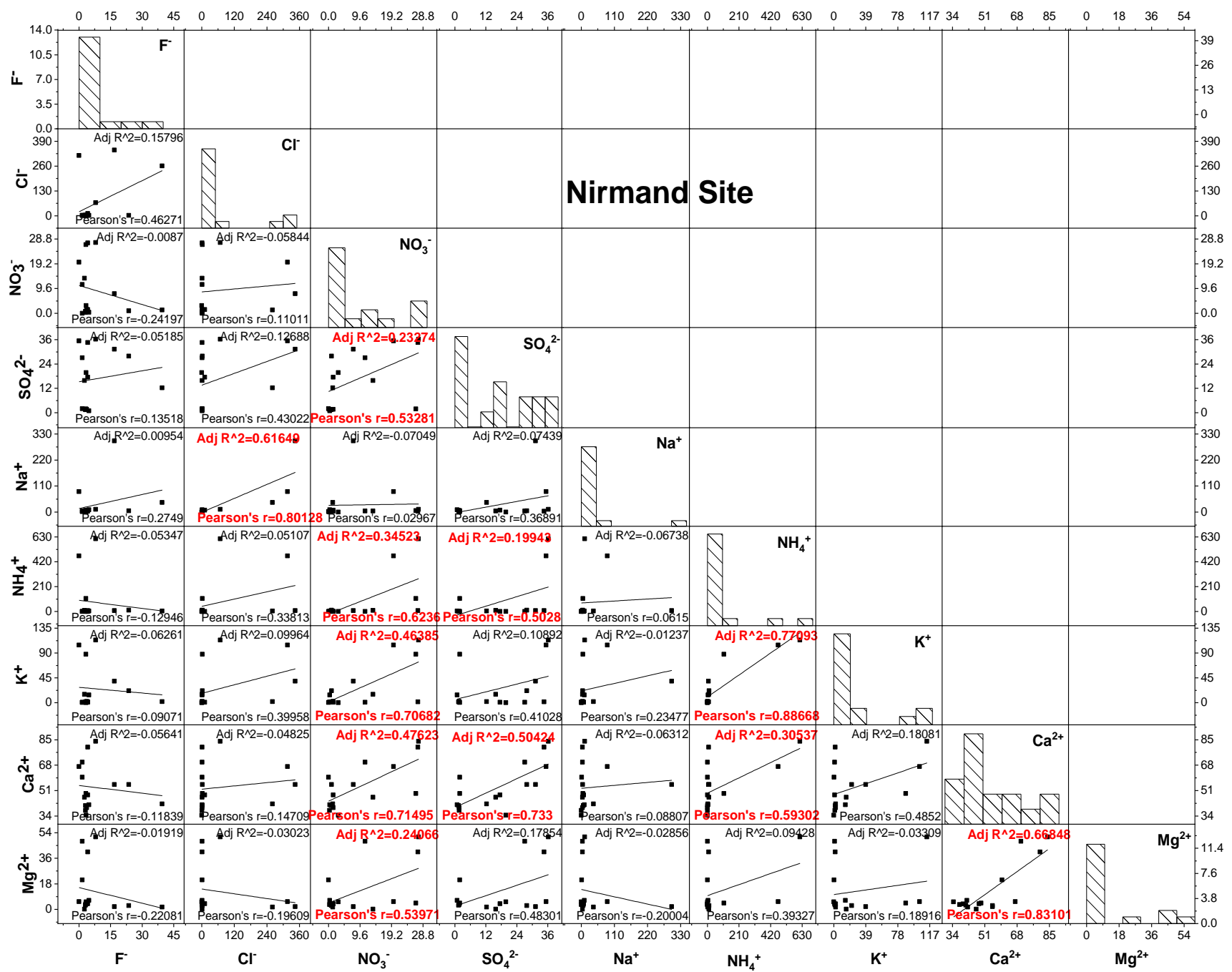

Fig. 7(c). Correlation matrix and frequency distribution graphs of soluble ions in snow at Nirmand site.

Table 5. Factor loading from PCA in snow at three sites.

\begin{tabular}{|c|c|c|c|c|c|c|c|c|c|c|}
\hline \multirow{2}{*}{ Species } & \multicolumn{4}{|c|}{ Leh } & \multicolumn{3}{|c|}{ Beerwah } & \multicolumn{3}{|c|}{ Nirmand } \\
\hline & 1 & 2 & 3 & 4 & 1 & 2 & 3 & 1 & 2 & 3 \\
\hline $\mathrm{F}^{-}$ & 0.68 & 0.51 & -0.21 & 0.02 & -0.53 & -0.21 & 0.51 & -0.33 & 0.29 & 0.44 \\
\hline $\mathrm{Cl}^{-}$ & -0.76 & 0.28 & 0.44 & -0.19 & 0.69 & -0.25 & -0.55 & 0.98 & 0.00 & -0.15 \\
\hline $\mathrm{NO}_{3}^{-}$ & -0.38 & 0.29 & 0.21 & 0.75 & 0.88 & -0.04 & 0.25 & 0.20 & 0.58 & 0.63 \\
\hline $\mathrm{SO}_{4}^{2+}$ & 0.29 & 0.37 & 0.45 & -0.59 & 0.83 & 0.28 & 0.22 & 0.31 & 0.80 & 0.42 \\
\hline $\mathrm{Na}^{+}$ & 0.63 & 0.52 & 0.37 & 0.29 & 0.66 & -0.38 & -0.23 & 0.54 & -0.70 & 0.12 \\
\hline $\mathrm{NH}_{4}{ }^{+}$ & 0.67 & 0.60 & 0.05 & 0.04 & 0.75 & 0.09 & 0.10 & 0.75 & 0.52 & -0.26 \\
\hline $\mathrm{K}^{+}$ & 0.32 & -0.50 & 0.75 & 0.05 & 0.51 & 0.30 & 0.64 & 0.98 & -0.02 & -0.14 \\
\hline $\mathrm{Ca}^{2+}$ & 0.57 & -0.66 & 0.31 & 0.15 & -0.35 & 0.79 & -0.16 & 0.24 & -0.51 & 0.64 \\
\hline $\mathrm{Mg}^{2+}$ & 0.81 & -0.39 & -0.32 & -0.01 & 0.23 & 0.78 & -0.31 & 0.28 & -0.53 & 0.53 \\
\hline Variance $\%$ & 35.46 & 22.38 & 15.32 & 11.76 & 40.33 & 18.38 & 14.02 & 34.91 & 26.14 & 17.48 \\
\hline
\end{tabular}

dust into the snow samples, which reflects a major crustal influence, whereas at Nirmand site $\mathrm{NH}_{4}{ }^{+}$contribution was highest, due to more agricultural or anthropogenic activity in this region. As the results suggested high concentrations of ions at the Leh site than Beerwah and Nirmand site, their limited deposition pathways at Leh reflected signatures of climate change over the upper Himalayan ranges and lesser transboundary sources during the advections from the west. This study also reveals the LTR of air pollutants being transported more to the lower regions than the upper region. The neutralizing factor analysis highlighting the influence of anthropogenic as well as crustal sources. The results of this study have indicated that soil dust, sea salts, burning of biomass and coal are the major contributor of atmospheric deposition. 


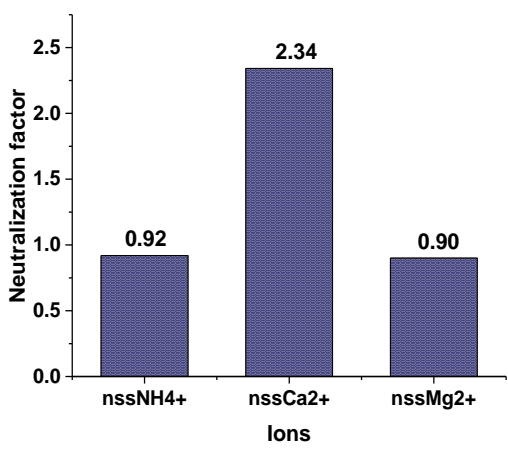

(A) Leh

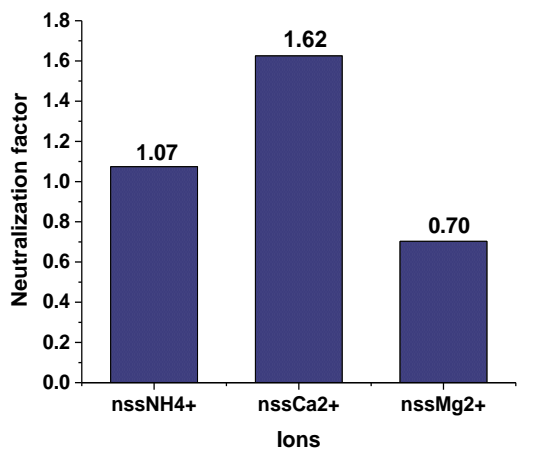

(B) Beerwah

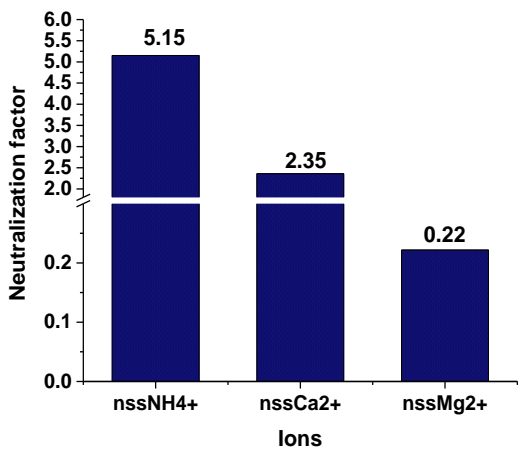

(C) Nirmand

Fig. 8. Neutralization factor of $\mathrm{nssCa}^{2+}, \mathrm{nssMg}^{2+}, \mathrm{NH}_{4}{ }^{+}$at (a) Leh, (b) Beerwah and (c) Nirmand sites (the axis break on $\mathrm{Y}-$ axis has given from 0.3 to 1.8 ).

\section{ACKNOWLEDGEMENT}

We sincerely thank the financial support received from DST-PURSE, UGC-UPE and CSIR- UGC to carry out this research work. The present work has been part of DRSNet network of Professor UC Kulshrestha's group.

\section{REFERENCES}

Ahmad, S. and Hasnain, S.I. (2001). Snow and stream-water chemistry of the Ganga headwater basin, Garhwal Himalaya, India. Hydrol. Sci. J. 46: 103-111. https://doi.org /10.1080/02626660109492803

Ali, K., Momin, G.A., Tiwari, S., Safai, P.D., Chate, D.M. and Rao, P.S.P. (2004). Fog and precipitation chemistry at Delhi, North India. Atmos. Environ. 38: 4215-4222. https://doi.org/10.1016/j.atmosenv.2004.02.055

Allen, R.J., Landuyt, W. and Rumbold, S.T. (2016). An increase in aerosol burden and radiative effects in a warmer world. Nat. Clim. Change 6: 269-274. https://doi. org/10.1038/nclimate2827

Avila, A. and Alacron, M. (1999). Relationship between precipitation chemistry and meteorological situations at a rural site in NE Spain. Atmos. Environ. 33: 1663-1677. https://doi.org/10.1016/S1352-2310(98)00341-0

Balestrini, R., Polesello, S. and Sacchi, E. (2014). Chemistry and isotopic composition of precipitation and surface waters in Khumbu valley (Nepal Himalaya): $\mathrm{N}$ dynamics of high elevation basins. Sci. Total Environ. 485: 681692. https://doi.org/10.1016/j.scitotenv.2014.03.096

Bisht, D.S., Tiwari, S., Srivastava, A.K., Singh, J.V., Singh, B.P. and Srivastava, M.K. (2015). High concentration of acidic species in rainwater at Varanasi in the IndoGangetic Plains, India. Nat. Hazard. 75: 2985-3003. https://doi.org/10.1007/s11069-014-1473-0

Bisht, D.S., Srivastava, A.K., Joshi, H., Ram, K., Singh, N., Naja, M. and Tiwari, S. (2017). Chemical characterization of rainwater at a high-altitude site "Nainital" in the central Himalayas, India. Environ. Sci. Pollut. Res. 24: 39593969. https://doi.org/10.1007/s11356-016-8093-z

Bouwman, A.F. and Van Der Hoek, K.W. (1997). Scenarios of animal waste production and fertilizer use and associated ammonia emission for the developing countries. Atmos. Environ. 31: 4095-4102. https://doi.org/10.1016/S13522310(97)00288-4

Budhavant, K.B., Rao, P.S.P., Safai, P.D. and Ah, K. (2009). Chemistry of monsoon and post-monsoon rains at a high altitude location, Sinhagad, India. Aerosol Air Qual. Res. 9: 65-79. https://doi.org/10.4209/aaqr.2008.07.0033

Budhavant, K.B., Rao, P.S.P. and Safai, P.D. (2014). Chemical composition of snow-water and scavenging ratios over costal Antarctica. Aerosol Air Qual. Res. 14: 666-676. https://doi.org/10.4209/aaqr.2013.03.0104

Charlson, R.J. and Rodhe, H. (1982). Factors controlling the acidity of natural rainwater. Nature 295: 683-695. https://doi.org/10.1038/295683a0

Cong, Z., Kang, S., Liu, X., and Wang, G. (2007). Elemental composition of aerosol in the Nam Co region, Tibetan Plateau, during summer monsoon season. Atmos. Environ. 41: 1180-1187. https://doi.org/10.1016/j.atmos env.2006.09.046

Cunningham, W.C. and Zoller, W.H. (1981). The chemical composition of remote area aerosols. J. Aerosol Sci. 12: 367-384. https://doi.org/10.1016/0021-8502(81)90026-4

Das, N., Das, R., Chaudhury, G.R. and Das, S.N. (2010). Chemical composition of precipitation at background level. Atmos. Res. 95: 108-113. https://doi.org/10.1016/j. atmosres.2009.08.006

Das, R., Das, S.N. and Misra, V.N. (2005). Chemical composition of rainwater and dustfall at Bhubaneswar in the east coast of India. Atmos. Environ. 39: 5908-5916. https://doi.org/10.1016/j.atmosenv.2005.06.030

Finlayson-Pitts, J.B. and Pitts, J.N. (1986). Atmospheric Chemistry: Fundamentals and Experimental Techniques. John Willey \& Sons, USA.

Fleming, Z.L., Monks, P.S. and Manning, A.J. (2012). Review: Untangling the influence of air-mass history in interpreting observed atmospheric composition. Atmos. Res. 104-105: 1-39. https://doi.org/10.1016/j.atmosres.20 11.09.009

Gajananda, K., Kuniyal, J.C., Momin, G.A., Rao, P.S.P., Safai, P.D., Tiwari, S. and Ali, K. (2005). Trend of Atmospheric Aerosols over the North Western Himalayan Region, India. Atmos. Environ. 39: 4817-4825. 
https://doi.org/10.1016/j.atmosenv.2005.01.038

Galloway, J.N., Schlesinger, W.H., Levy, H., Michaels, A., and Schnoor, J.L. (1995). Nitrogen fixation: Anthropogenic enhancement-environmental response. Global Biogeochem. Cycles 9: 235-352. https://doi.org/10.1029/95GB00158

Gunz, D.W. and Hoffmann, M.R. (1990). Field investigations on the snow chemistry in central and southern CaliforniaI. Inorganic ions and hydrogen peroxide. Atmos. Environ. 24: 1661-1671. https://doi.org/10.1016/0960-1686(90)90 $500-\mathrm{M}$

Huang, J., Kang, S., Guo, J., Zhang, Q., Xu, J., Jenkins, M.G. and Wang, K. (2012). Seasonal variations, speciation and possible sources of mercury in the snowpack of Zhadang glacier, Mt. Nyainqêntanglha, southern Tibetan Plateau. Sci. Total Environ. 429: 223-230. https://doi.org/ 10.1016/j.scitotenv.2012.04.045

Jain, M., Kulshrestha, U.C., Sarkar A.K. and Parashar, D.C. (2000). Influence of crustal aerosols on wet deposition at urban and rural sites in India. Atmos. Environ. 34: 5129 5137. https://doi.org/10.1016/S1352-2310(00)00350-2

Jenkins, M.D, Drever, J.J., Reider, R.G. and Buchanan, T. (1987). Chemical composition of fresh snow on Mount Everest. J. Geophys. Res. 92: 10999-11002. https://doi.org/10.1029/JD092iD09p10999

Kang, S.C., Mayewski, P.A., Qin, D.H., Sneed, S.R., Ren, J.W. and Zhang, D.Q. (2004). Seasonal differences in snow chemistry from the vicinity of Mt. Everest, central Himalayas. Atmos. Environ. 38: 2819-2829. https://doi.org/ 10.1016/j.atmosenv.2004.02.043

Kapoor, R.K. and Paul, S.K. (1980). A study of the chemical components of aerosols and snow in the Kashmir region. Tellus 32: 33-41. https://doi.org/10.3402/tellusa.v32i1.10 478

Kaya, G. and Tuncel, G. (1997). Trace element and major ion composition of wet and dry deposition in Ankara, Turkey. Atmos. Environ. 31: 3985-3998. https://doi.org/ 10.1016/S1352-2310(97)00221-5

Keene, W.C., Pszenny, A.P., Galloway, J.N. and Hawley, M.E. (1986). Sea-salt corrections and interpretation of constituent ratios in marine precipitation. J. Geophys. Res. 91: 66476658. https://doi.org/10.1029/JD091iD06p06647

Khan, M.F., Maulud, K.N.A., Latif, M.T., Chung, J.X., Amil, N., Alias, A., Nadzir, M.S.M., Sahani, M., Mohammad, M., Jahaya, M.F., Hassan, H., Jeba, F., Tahir, N.M. and Abdullah, S.M.S. (2018). Physicochemical factors and their potential sources inferred from long-term rainfall measurements at an urban and a remote rural site in tropical areas. Sci. Total Environ. 613: 1401-1416. https://doi.org/10.1016/j.scitotenv.2017.08.025

Kulshrestha, M.J., Kulshrestha, U.C., Parashar, D.C. and Vairamani, M. (2003). Estimation of $\mathrm{SO}_{4}$ contribution by dry deposition of $\mathrm{SO}_{2}$ onto the dust particles in India. Atmos. Environ. 37: 3057-3063. https://doi.org/10.1016/ S1352-2310(03)00290-5

Kulshrestha, U.C., Sarkar, A.K., Srivastava, S.S. and Parashar, D.C. (1995). Wet-only and bulk deposition studies at New Delhi (India). Water Air Soil Pollut. 85: 2137-2142. https://doi.org/10.1007/BF01186150

Kulshrestha, U.C., Sarkar, A.K., Srivastava, S.S. and Parashar,
D.C. (1996). Investigation into atmospheric deposition through precipitation studies at New Delhi (India). Atmos. Environ. 30: 4149-4154. https://doi.org/10.1016/13522310(96)00034-9

Kulshrestha, U.C., Jain, M., Saxena, A.K., Kumar, A. and Parashar, D.C. (1997). Contribution of sulphate aerosol to the rain water at urban site in India. Proceedings of IGAC international symposium on atmospheric chemistry and future global environment, Nagoya congress center, Nagoya, Japan, 11-13 November, 1997.

Kulshrestha, U.C., Kulshrestha, M.J., Sekar, R., Sastry, G.S.R. and Vairamani, M. (2003). Chemical characteristics of rainwater at an urban site of south Central India. Atmos. Environ. 37: 3019-3026. https://doi.org/10.1016/S13522310(03)00266-8

Kulshrestha, U.C. (2013). Acid Rain. In Encyclopedia of Environmental Management, Four Volume Set, Jorgensen, S.E. (Ed.), Taylor and Francis, Manila Typesetting Company, New York, pp. 8-22.

Kulshrestha, U.C., Granat, L., Engardt, M. and Rodhe, H. (2005). Review of precipitation monitoring studies in India - a search for regional patterns. Atmos. Environ. 39: 7403-7419. https://doi.org/10.1016/j.atmosenv.2005.08.035

Kulshrestha, U.C. and Kumar, B. (2014). Airmass trajectories and long range transport of pollutants: review of wet deposition scenario in South Asia. Adv. Meteorol. 2014: 596041. https://doi.org/10.1155/2014/596041

Kumar, B., Gupta, G.P., Singh, S., Lone, F.A. and Kulshrestha U.C. (2015). Snow Chemistry at Mukteshwar in Central Himalayan Region of India. Mod. Chem. Appl. 3: 160. https://doi.org/10.4172/2329-6798.1000160

Kumar, B., Singh, S., Gupta, G.P., Lone, F.A. and Kulshrestha, U.C. (2016). Long range transport and wet deposition fluxes of major chemical species in snow at Gulmarg in North Western Himalayas (India). Aerosol Air Qual. Res. 16: 606-617. https://doi.org/10.4209/aaqr. 2015.01.0056

Kuniyal, J.C., Sharma, M., Chand, K. and Mathela, C.S. (2013). Water soluble ionic components in particulate matter $\left(\mathrm{PM}_{10}\right)$ during high pollution episode days at Mohal and Kothi in the North-western Himalya, India. Aerosol Air Qual. Res. 15: 529-543. https://doi.org/10.4209 /aaqr.2013.09.0297

Kuylenstierna, J.C.I., Rodhe, H., Cinderby, S. and Hicks, K. (2001). Acidification in developing countries: Ecosystem sensitivity and the critical load approach on a global scale. Ambio 30: 20-28. https://doi.org/10.1579/0044-744730.1 .20

Li, C., Kang, S., Zhang, Q. and Kaspari, S. (2007). Major ionic composition of precipitation in the Nam Co region, Central Tibetan Plateau. Atmos. Res. 85: 351-360. https://doi.org/10.1016/j.atmosres.2007.02.006

Liu, B., Kang, S., Sun, J., Zhang, Y., Xu, R., Wang, Y. and Cong, Z. (2013). Wet precipitation chemistry at a highaltitude site $(3,326 \mathrm{~m}$ asl $)$ in the southeastern Tibetan Plateau. Environ. Sci. Pollut. Res. 20: 5013-5027. https://doi.org/10.1007/s11356-012-1379-x

Lone, F.A. and Khan, M.A. (2007). Himalayan snow chemistry: Chemical composition of fresh snow samples 
from Kashmir valley. Curr. World Environ. 2: 17-20. http://dx.doi.org/10.12944/CWE.2.1.03

Marinoni, A., Polesello, S., Smirraglia, C. and Valssecchi, S. (2001). Chemical composition of fresh snow samples from the southern slope of Mt. Everest region (KhumbuHimal region, Nepal). Atmos. Environ. 35: 3183-3190. https://doi.org/10.1016/S1352-2310(00)00488-X

Mayewski, P.A., Lyons, W.B. and Ahmad, N. (1983). Chemical Composition of a High Altitude Fresh Snowfall in the Ladakh, Himalayas. Geophys. Res. Lett. 10: 105108. https://doi.org/10.1029/GL010i001p00105

Naik, M.S., Khemani, L.T., Momin, G.A., Rao, P.S. and Safai, P.D. (1995). Chemical composition of fresh snow from Gulmarg, North India. Environ Pollut. 87: 167-171. https://doi.org/10.1016/0269-7491(94)P2603-7

Niu, H., He, Y., Zhu, G., Xin, H. and Du, J. (2013). Environmental implications of the snow chemistry from Mt. Yulong, southeastern Tibetan Plateau. Quat. Int. 313314: 168-178. https://doi.org/10.1016/j.quaint.2012.11.019

Norman, M., Das, S.N., Pillai, A.G., Granat, L. and Rodhe, H. (2001). Influence of air mass trajectories on the chemical composition of precipitation in India. Atmos. Environ. 35: 4223-4235. https://doi.org/10.1016/S13522310(01)00251-5

Rahn, K.A. (1976). The chemical Composition of the atmospheric aerosol: Technical report. Graduate School of Oceanography, University of Rhode Island, Kingston.

Reynolds, B. (1983). The chemical composition of snow at a rural upland site in Mid-Wales. Atmos. Environ. 17: 18481851. https://doi.org/10.1016/0004-6981(83)90193-2

Rodhe, H., Dentener, F. and Schultz, M. (2002). The global distribution of acidifying wet deposition. Environ. Sci. Technol. 36: 4382-4388. https://doi.org/10.1021/es020057g

Rohrbough, J.A., Davis, D.R. and Bales, R.C. (2003). Spatial variability of snow chemistry in an alpine snow peak, Southern Wyoming. Water Resour. Res. 39: 1190. https://doi.org/10.1029/2003WR002067

Roy, A., Chatterjee, A., Tiwari, S., Sarkar, C., Das, S.K., Ghosh, S.K. and Raha, S. (2016). Precipitation chemistry over urban, rural and high altitude Himalayan stations in eastern India. Atmos. Res. 181: 44-53. https://doi.org/10. 1016/j.atmosres.2016.06.005

Safai, P.D., Rao, P.S.P., Momin, G.A., Ali, K., Chate, D.M. and Praveen, P.S. (2004). Chemical composition of precipitation during 1984-2002 at Pune, India. Atmos. Environ. 38: 17051714. https://doi.org/10.1016/j.atmosenv.2003.12.016

Sanusi, A., Wortham, H., Millet, M. and Mirabel, P. (1996). Chemical composition of rain water in Eastern France. Atmos. Environ. 30: 59-71. https://doi.org/10.1016/13522310(95)00237-S

Satyanarayana, J., Reddy, L.A.K., Kulshrestha, M.J., Rao, R.N. and Kulshrestha, U.C. (2010). Chemical composition of rain water and influence of airmass trajectories at a rural site in an ecological sensitive area of Western Ghats (India). J. Atmos. Chem. 66: 101. https://doi.org/10.1007/ s10874-011-9193-2

Seinfeld, J.H. and Pandis, S.N. (2006). Atmospheric Chemistry and Physics - From Air Pollution to Climate Change (2nd Edition), John Wiley \& Sons, New York.
Shrestha, A.B., Wake, C.P., Dibb, J.E. and Whitlow, S.I. (2002). Aerosol and precipitation chemistry at a remote Himalayan site in Nepal. Aerosol Sci. Technol. 36: 441456. https://doi.org/10.1080/027868202753571269

Singh, A. K., Mondal, G. C., Kumar, S., Singh, K. K., Kamal, K. P., and Sinha, A. (2007). Precipitation chemistry and occurrence of acid rain over Dhanbad, coal city of India. Environmental monitoring and assessment. 125(1-3): 99-110.

Singh, S. and Kulshrestha, U.C. (2012). Abundance and distribution of gaseous ammonia and particulate ammonium at Delhi, India. Biogeosciences 9: 5023-5029. https://doi.org/10.5194/bg-9-5023-2012

Singh, S., Gupta, G.P., Kumar, B. and Kulshrestha, U.C. (2014). Comparative study of indoor air pollution using traditional and improved cooking stoves in rural households of Northern India. Energy Sustainable Dev. 19: 1-6. https://doi.org/10.1016/j.esd.2014.01.007

Team, C.W., Pachauri, R.K. and Meyer, L.A. (2014). IPCC, 2014: Climate change 2014: synthesis report. Contribution of Working Groups I. II and III to the Fifth Assessment Report of the intergovernmental panel on Climate Change. IPCC, Geneva, Switzerland, 151.

Tiwari, S., Kulshrestha, U.C., Padmanabhamurty, B. (2007). Monsoon rain chemistry and source apportionment using receptor modeling in and around National Capital Region (NCR) of Delhi, India. Atmos. Environ. 41: 5595-5604. https://doi.org/10.1016/j.atmosenv.2007.03.003

Tiwari, S., Chate, D.M., Bisht, D.S., Srivastava, M.K. and Padmanabhamurty, B. (2012). Rainwater chemistry in the North Western Himalayan Region, India. Atmos. Res. 104-105: 128-138. https://doi.org/10.1016/j.atmosres.2011. 09.006

Toom-Sauntry, D. and Barrie, L.A. (2002). Chemical composition of snowfall in the high Arctic:1990-1994. Atmos. Environ. 36: 2683-2693. https://doi.org/10.1016/ S1352-2310(02)00115-2

Valsecchi, S., Smiraglia, C., Tartari, G. and Polesello, S. (1999). Chemical composition of Monsoon deposition in the Everest region. Sci. Total Environ. 226: 187-199. https://doi.org/10.1016/S0048-9697(98)00393-3

Walker, T.R., Young, S.D., Crittenden, P.D. and Zhang, H. (2003). Anthropogenic metal enrichment of snow and soil in north- eastern European Russia. Environ. Pollut. 121: 11-21. https://doi.org/10.1016/S0269-7491(02)00212-9

Wang, Y.Q, Zhang, X.Y. and Draxler, R.R. (2009). TrajStat: GIS-based software that uses various trajectory statistical analysis methods to identify potential sources from longterm air pollution measurement data. Environ. Modell. Software 24: 938-939. https://doi.org/10.1016/j.envsoft. 2009.01.004

Xu, J., Zhang, Q., Li, X., Ge, X. and Xiao, C. (2013). Dissolved organic matter and inorganic ions in a central Himalayan glacier--insights into chemical composition and atmospheric sources. Environ. Sci. Technol. 47: 61816188. https://doi.org/10.1021/es4009882

Zhang, M., Wang, S., Wu, F., Yuan, X. and Zhang, Y. (2007). Chemical compositions of wet precipitation and anthropogenic influences at a developing urban site in 
southeastern China. Atmos. Res. 84: 311-322. https://doi.org/10.1016/j.atmosres.2006.09.003

Zhang, Y., Kang, S., Li, C., Cong, Z. and Zhang, Q. (2012). Wet deposition of precipitation chemistry during 2005 2009 at a remote site (Nam Co Station) in central Tibetan Plateau. J. Atmos. Chem. 69: 187-200. https://doi.org/10. 1007/s10874-012-9236-3

Zhang, Y., Xiu, G., Wu, X., Moore, C.W. and Wang, J. (2013). Characterization of mercury concentrations in snow and potential sources, Shanghai, China. Sci. Total Environ. 449:
434-442. https://doi.org/10.1016/j.scitotenv.2013.01.088 Zhu, G.F., Pu, T., He, Y.Q., Shi, P.J. and Zhang, T. (2012). Seasonal variations of major ions in fresh snow at Baishui Glacier No., Yulong Mountain, China. Environ Earth Sci. 69: 1-10. https://doi.org/10.1007/s12665-012-1928-0

Received for review, June 23, 2019

Revised, March 4, 2020

Accepted, March 6, 2020 